\title{
Semecarpus anacardium Linn. leaf extract exhibits activities against breast cancer and prolongs the survival of tumor bearing mice
}

\author{
Rajesh Kumar Singh ${ }^{1 \& 2}$, Amit Ranjan ${ }^{1}$, Ruchita Tripathi ${ }^{2}$, Sumit Singh Verma $^{3}$, Vinamra Sharma ${ }^{4}$ Monika Singh $^{5}$, \\ Subash Chandra Gupta ${ }^{3}$, Anil Kumar Singh ${ }^{2}$ and Akhileshar Kumar Srivastava ${ }^{6} *$ \\ ${ }^{1}$ Centre of Experimental Medicine and Surgery, Institute of Medical Sciences, Banaras Hindu University, Varanasi. India. \\ ${ }^{2}$ Department of Dravyaguna, Institute of Medical Sciences, Banaras Hindu University, Varanasi, India. \\ ${ }^{3}$ Department of Biochemistry, Institute of Science, Banaras Hindu University, Varanasi, India. \\ ${ }^{4}$ Department of Rasa Shastra \& Bhaishajya Kalpana, Institute of Medical Sciences, Banaras Hindu University, Varanasi, India. \\ ${ }^{5}$ School of Biomedical Engineering, Indian Institute of Technology (BHU), Varanasi, India. \\ ${ }^{6}$ CSIR- Central Food Technological Research Institute, Mysuru-570020, India
}

*Correspondence:

Dr. Akhileshar Kumar Srivastava

CSIR-Central Food Technological Research Institute, Mysuru-570020, India

Contact No.: +91-8604664864; Email Id: akhileshwar.kumar2@gmail.com 


\section{ABSTRACT}

Semecarpus anacardium Linn. is a commonly used Ayurvedic medicinal plant which nuts have been described in Ayurveda and Sidda system of medicine to treat clinical ailments such as vitiligo, inflamation, microbial infection, geriatric problem, baldness and neuro related problems. In this study, anti-cancer activity of the leaves of Semecarpus anacardium Linn was evaluated for future drug development. The phytochemical screening was done by GC-MS analysis, cytotoxicity was examined using MTT assay, mode of cell death was evaluated by fluorescence microscopy and finally antitumor activity was determined in EAC cell induced tumor bearing mice. The ethyl acetate extract from the leaves of the plant induced cytotoxicity in cancer cells in

27 a dose dependent manner ( $\mathrm{IC}_{50}: 0.57 \mu \mathrm{g} / \mathrm{ml}$ in $\mathrm{MCF}-7$ cells) in different cancer cell lines. The 28 non-malignant cells were relatively insensitive to the extract. The staining with acridine orange, ethidium bromide and DAPI confirmed that the extract induced apoptosis in cancer cells. Furthermore, the extract induced cell cycle arrest at G1 phase and suppressed cancer cell migration. An oral administration of the extract suppressed the tumor growth in mice model bearing ehrlich ascites carcinoma cells. The ethyl acetate extract was also found to prolong the survival of tumor bearing mice. Overall, these observations suggest the anticancer activities of the ethyl acetate extract of the leaves of $S$. anacardium. The study opens a new window to examine the phytochemical constituents from the leaves of the plant responsible for the anticancer activities.

Keywords: Semecarpus anacardium; Ayurveda; Breast cancer; Apoptosis; Cell migration; Phytochemical. 


\section{INTRODUCTION}

Breast Cancer is the most common cancer amongst the women and a major health issue globally. Its incidence in 2018 was 2.09 million new cases diagnosed and 0.63 million mortality with a projection of 3.06 million new cases and 0.99 million death in $2040{ }^{1}$. Chemotherapy remains the common pharmacological approach for its treatment with many drawbacks including severe toxic side effects, leading to death in cancer patients ${ }^{2}$. These drugs are often cytotoxic and induce cancer cell death in solid tumors either by cell cycle arrest, DNA synthesis inhibition, necrotic cell death, or by inducing apoptosis. There are several known adverse effects of these drugs which cause severe damage to the vital organs and normal proliferating cells such as heart, liver, kidneys, hair follicles, stem cells, etc ${ }^{3,4}$. New efficient and non toxic chemotherapeutic agents are the need of time to overcome the problem. Natural products have been used to treat many clinical ailments since antiquity ${ }^{5}$ as described in different traditional system of medicine across the world. Ayurveda, one of the traditional system of medicine, specially popular in Indian subcontinent, which describes the holistic approach for the treatment of human clinical ailments using processed medicinal plants, some animal parts and minerals ${ }^{6}$. The medicinal plants described in Ayurveda may serve as a prime source for rational drug designing for many diseases including cancer. A large number of phytoconstituents are isolated from Ayurvedic medicinal plants which are promising lead molecules such as alkaloids from Rauwolfia serpentina, Holarrhena antidysenterica, Piper longum, Withania somnifera, Curcuma longa etc. for the treatment of hypertension, Amoebiasis, cough, stress and cancer, respectively ${ }^{7}$. Several compounds isolated from Azadirachta indica and Bharangin from Pigmacopremna herbacea shows potent anticancer property with regulating numerous signal pathways ${ }^{8,9}$. Several compounds isolated from medicinal plants are in clinical trial for cancer prevention such as curcumin, flavopiridol, genistein, capsaicin, berberine, boswellic acid, caffeic acid, resveratrol, etc ${ }^{10}$.

Semecarpus anacardium Linn. (Family: Anacardiaceae) is an Ayurvedic medicinal plant, described for treatment of several clinical ailments such as inflammation, vitiligo, neural problem, microbial infection, geriatric problem, diabetes, cancer and baldness ${ }^{11}$. Its fruit has been used in numerous Ayurvedic formulations since a time ago. Recent studies have explored its various properties such as antioxidant, antimicrobial, hypoglycemic, antiinflammatory, anticancerous, antiatherogenic, CNS stimulant, skin diseases and hair growth promoter ${ }^{12}$. The recent studies also advocate the different properties of its nuts like antioxidant and cytotoxicity in cancer cells of breast, liver, lung, cervical and blood ${ }^{12-14}$. It also has antitumor activity in tumor bearing animal model. The nut contains bhilawanols, cardol, anacardic acid, semecarpol and anacardol ${ }^{15,16}$. Its two contents, bhilawanol and anacardic acids are immunogenic and their exposure causes irritation, blisters, contact dermatitis and toxicity ${ }^{17}$.

The nuts of the plant are described for several ethnopharmacological properties in different Ayurvedic formulations including anticancer property, but there are no studies have been carried out to investigate the anticancer activity of other parts of the plant except the fruit. Therefore, in this study we carried out to explore the anticancer property of the leaves. Here, it is important to 
focus that leaves are alternative and ecofriendly source of a plant, may be used without altering any biodiversity.

Our study showed that the ethyl acetate extract of $S$. anacardium Linn. leaves induces apoptosis and arrests the cell cycle progression in G1 phase and more importantly, the oral administration of the extract shows inhibition of tumor growth, delays the tumor associated death and enhances the survival in tumor bearing mice significantly. The results show that the potency of $S$. anacardium leaves extract for being used as raw material for future anticancer drug discovery to treat the breast cancer. Thus, this study explores the anticancer property of leaves for the first time with less toxicity and more efficacy as compare to the nuts.

\section{METHODS}

\section{Collection of plant materials and phytochemical analysis}

The leaves of Semecarpus anacardium Linn. were collected in the spring season of 2017 from Banaras Hindu University, Varanasi, India and identified by the Department of Dravyaguna (Ayurvedic Pharmacognosy \& Pharmacology), Faculty of Ayurveda, Institute of Medical Sciences, Banaras Hindu University, Varanasi, India (Accession Number: DG/18/171).

96

97

98

99

100

101

102

103

104

105

106

107

108

109

110

111

112

113

114

115

116

The plant materials were dried at room temperature for two weeks and grinded into a coarse powder through electrical domestic grinder. The $1 \mathrm{~kg}$ of leaves powder was macerated up to $24 \mathrm{~h}$ with continuous stirring in 5 litres of petroleum ether, ethyl acetate and methanol respectively three times. The supernatant was recovered by filtration through Whatman filter paper of $11 \mu \mathrm{m}$ pore size. Further, each filtrate was completely dried by rotary vacuum evaporator in reduced pressure ${ }^{18}$. The compounds of ethyl acetate extract of S. anacardium leaves (SLE) were assessed by Gas chromatography-mass spectrometry (GC-MS), the JEOL GCMATE II GC-MS at SAIF, IIT Madras using standard procedure ${ }^{19}$. The data were matched with the standards ${ }^{20,21}$.

\section{Cell Culture}

Human breast adenocarcinoma (MCF-7) cells, human triple negative breast carcinoma (MDAMB-231) cells, human colon adenocarcinoma (HCT-15) cells, mouse insulinoma (MIN-6) cells, mice undifferentiated breast carcinoma (Ehrlich-Lettre ascites carcinoma, EAC) cells and mice fibroblast (NCTC clone 929, L929) cells were procured from National Centre for Cell Sciences (NCCS), Pune, India. The cells were cultured in DMEM with high-glucose, sodium bicarbonate, L-glutamine and sodium pyruvate which supplemented with $10 \%$ fetal bovine serum (FBS) and $1 \%$ antibiotics-antimycotic $(10000 \mathrm{unit} / \mathrm{mL}$ of penicillin $\mathrm{G}, 10 \mathrm{mg} / \mathrm{mL}$ of streptomycin sulfate and $25 \mu \mathrm{g} / \mathrm{mL}$ amphotericin $\mathrm{B}$ in $0.9 \%$ normal saline) solution at $37{ }^{\circ} \mathrm{C}$ in a humidified environment with $5 \% \mathrm{CO}_{2}$ gas. About $70-80 \%$ confluent cells at $\log$ phase were harvested by trypsinization (1X Trypsin-EDTA Solution, Himedia) ${ }^{18}$. MCF-7 cells were used throughout the study while EAC and L929 cells were used in cytotoxicity assay.

\section{Cytotoxicity assay}


MTT assay was performed for evaluation of the cytotoxicity of the leaves extracts in which tetrazolium rings of 3-[4,5-dimethylthiazol-2-yl]-2,5-diphenyl tetrazolium bromide is cleaved by mitochondrial enzyme succinate dehydrogenase of live cells. The yellowish MTT solution is turned into water-insoluble violet colored formazan crystals depending on the number of viable cells. This assay is also sensitive, reliable, quantitative and colorimetric method to measure cell viability. The $100 \mu \mathrm{l}$ of cell solution in fresh media at a cell density of $1 \mathrm{X} 10^{4}$ cells $/ \mathrm{ml}$ was seeded in each well of 96-well plate and incubated overnight. Then, the old culture media was replaced with $200 \mu \mathrm{l}$ fresh media and treated with the extracts by performing serial dilution which was further incubated for 48 hours. On completion of treatment duration, the treated culture media was replaced with $100 \mu 1$ of 3-[4,5-dimethylthiazol-2-yl]-2,5-diphenyl tetrazolium bromide (MTT) solution at a concentration of $0.5 \mathrm{mg} / \mathrm{ml}$ incomplete culture media, i.e., the culture media without fetal bovine serum was kept for 4 hours at $37{ }^{\circ} \mathrm{C}$. The treated cells were centrifuged at $750 \mathrm{rpm}$ for 5 minutes (Remi R8C) and the supernatant was replaced with $100 \mu \mathrm{l}$ DMSO to solubilize water-insoluble purple colored-formazan crystal and absorbance was measured at $570 \mathrm{~nm}$ using microtitre plate reader (Biorad, India) ${ }^{18}$. The percentage of cell viability was calculated as Percentage of cell viability $=(\mathrm{OD}$ of the treated cells $/ \mathrm{OD}$ of the untreated cells as control) $\times 100$, then $\mathrm{IC}_{50}$ was calculated.

134

135

136

137

138

139

140

141

142

143

144

145

146

147

148

149

150

151

152

153

154

155

\section{Analysis of Cell morphology}

The MCF-7 cells were seeded into 96 wells plate and then old media were replaced with fresh media after $24 \mathrm{~h}$, the extract was administred and further washed with $10 \mathrm{mM}$ PBS (pH 7.4) aftr incubation of $24 \mathrm{~h}$ and observed under the inverted light microscope (Dewinter, India) at 40X

objective lense ${ }^{18,22}$. Further, Acridine orange (AO) and Ethidium bromide (EtBr) double staining was used for detection of the mode of cell death. Acridine orange is a cell permeable dye which binds with the nucleic acid to emit green fluorescence while ethidium bromide can enter the cell membrane and binds to the nucleic acid to emit red fluorescence. MCF-7 cells were seeded into 96 wells plate $\left(1 \times 10^{4}\right.$ cells per well) for $24 \mathrm{~h}$ at $37{ }^{\circ} \mathrm{C}$ with fresh culture medium and the extract to test the drug, Paclitaxel was used as control positive group while $10 \mathrm{mM}$ PBS was taken as control negative. Then the culture media were removed and cells were washed with $10 \mathrm{mM}$ PBS ( $\mathrm{pH}$ 7.4) and incubated for further 30 minutes in $100 \mu \mathrm{g} / \mathrm{ml} \mathrm{AO}$ and $100 \mu \mathrm{g} / \mathrm{ml} \mathrm{EtBr}$ in dark. It was washed with $10 \mathrm{mM}$ PBS ( $\mathrm{pH} 7.4)$ and finally cells were examined underthe fluorescence inverted microscope (Dewinter, India) using $40 \times$ objective lense ${ }^{18,22}$.

\section{Analysis of nuclear morphology}

Nuclear Morphology was studied by DAPI (4'-6-diamidino-2-phenylindole) stain (Genetix, India) which forms fluorescent complexes with natural double-stranded DNA[22]. Human breast cancer (MCF-7) cells were seeded at a density of 1 X 104 cells per well and incubated for 24 hours. Then, the treatments were given as per previous experiment followed by washing of cells with PBS and stained with DAPI solution. After 30 minute incubation, the cells were again washed with $10 \mathrm{mM}$ PBS (pH 7.4) and cells were studied by fluorescence inverted microscope using the blue filter ${ }^{18}$. 


\section{Cell cycle analysis}

The cell cycle analysis was perfomed with slight modifiedification of previously described method ${ }^{8}$. In brief, the cells were washed with PBS at the end of the treatment time, then stained with $70 \%$ chilled methanol, treated with RNaseA and stained with PI. The population of cells in different phases of the cell cycle was determined by FACScan and the analysis was performed by Cell Quest software (Becton Dickinson).

\section{Scratch wound healing assay}

MCF-7 cells were grown upto $80 \%$ confluency and trypsinized for seeding into 6 -well plate $(1 \times$ $10^{5}$ cells $/ \mathrm{ml}$ ) at $37{ }^{\circ} \mathrm{C}$ for $24 \mathrm{~h}$ in DMEM medium. Further, media were replaced with fetal bovine serum free media further $24 \mathrm{~h}$ and scratch wound was created in the middle of the well with a sterile $20 \mu \mathrm{l}$ pipette tip and washed with $10 \mathrm{mM}$ PBS thrice. $1 \mathrm{ml}$ of complete medium was given to the wound containing cells and extract was administrated in test group while medium in control group. The cells were examined at an interval of $24 \mathrm{~h}, 48 \mathrm{~h}$ and $72 \mathrm{~h}$. Images were analyzed for cellular migration by inverted microscope (Dewinter, India) using 10X objective lense ${ }^{18}$.

\section{Animal model and Ethical statement}

For in vivo studies, Swiss albino mice of either sex weighing 18-22 grams of about 8-10 weeks old were procured from the central animal facility, Institute of Medical Sciences, Banaras Hindu University, Varanasi, India with approval of the institutional ethical committee (Dean/2016/CAEC/337). The animals were kept in polypropylene cages and provided standard pellet diet (Agro Corporation Pvt. Ltd., Bengaluru, India) and water ad libitum. The mice were accommodated under controlled temperature $\left(27 \pm 2{ }^{\circ} \mathrm{C}\right)$ and humidity with a 12 hours light and dark cycle by following CPCSEA guidelines for experimental study.

\section{Antitumor evaluation}

To evaluate antitumor activity, a total of 18 tumor-bearing mice and 6 normal mice were divided into four groups. Mice of group I, group II and group III were administered $20 \mathrm{mg} / \mathrm{kg}$ body weight Paclitaxel, $100 \mathrm{mg} / \mathrm{kg}$ bodyweight BLEA and equal volume of water (as BLEA suspended in it) respectively, while group IV was normal mice without tumor. All mice of group I and Group II were given respective drugs regularly throughout the experimental period of 28 days. The mice of group IV were given no treatment to served as control negative group. Tumor size was measured using vernier calipers on alternative days for tumor animals and tumor volume was calculated using the formula $\mathrm{V}=0.5 \times \mathrm{a} \times \mathrm{b} 2$, where ' $\mathrm{a}$ ' and ' $\mathrm{b}$ ' indicates the major and minor diameter, respectively. At the end of 28th day of experimental period, animals from each group were sacrificed to collect kidney, liver, thigh and spleen were collected from Paclitaxel, BLEA treated, tumor and normal animals and were evaluated for morphological changes using hematoxylin-eosin stained histological slides ${ }^{23}$. 


\section{Animal survival study}

The effect of BLEA on life span of the tumor-bearing mice was assessed. For this study, total 12 mice have received EAC cells in their left thigh. They were further divided into two groups (6 mice in each). Group I was served as tumor control and group II received oral administration of BLEA $100 \mathrm{mg} / \mathrm{kg}$ body weight daily till the survival of last animal, starting after 7 days of tumor (EAC) cell injection.

The life span of BLEA treated mice was calculated and compared with untreated tumor-bearing animals. The life span of experimental animals was monitored and calculated by using the following formula $[(\mathrm{T}-\mathrm{C}) / \mathrm{C}] \times 100$, where ' $\mathrm{T}$ ' indicates the number of days the treated animals survived and ' $\mathrm{C}$ ' indicates that number of days that tumor animals survived ${ }^{2}$.

\section{Histology}

The tissues were collected from control, BLEA treated animals, and further processed for histological evaluations ${ }^{24}$. The excised tissues were fixed in $4 \%$ neutral saline formalin, dehydrated in alcohol and embedded in paraffin wax. The section $(5 \mu \mathrm{m})$ of tissues was cut using Microtome (Leica Biosystems, Germany) and then stained with haematoxylin and eosin. Images of all tissue sections were captured using light microscope (Dwinter).

\section{In silico studies}

ADME Screening: The parameters of pharmacokinetics such as absorption, distribution, metabolism and elimination (ADME) play an important role in drug discovery and development 25. The ADME properties of compounds were analyzed using SwissADME (http://www.swissadme.ch) and the data were recorded to analyze the possibility of identified compounds to be the drug candidates ${ }^{26}$.

Molecular docking studies: All identified phytochemicals were used as ligands and their structures were drawn using Chembiodraw Ultra 14.0 (Cambridge Soft) and saved as pdb file. Crystal structures of receptor proteins CDK2 (protein ID: 1W0X) was downloaded from Protein Data Bank (https://www.rcsb.org/structure/2B53), then water molecules and ligand were removed. Patchdock (Tel Aviv University, Israel) was used for molecular docking studies using CDK2 receptor protein and ligands considering settings as clustering RMSD 4.0 and complex type default ${ }^{27}$. The resultant complex of receptor-ligand with solution number, docking score, area and six-dimensional transformation space was recorded. The docking solutions obtained in Patchdock were further refined with FireDock (Tel Aviv University, Israel) and top 10 solutions among 1000 rescored solution were downloaded with global energy, atomic contact energy, attractive Van der Waals and considered for further analysis. Each complex of ligand-receptor obtained through FireDock was ranked based on their minimum global energy and Chimera 1.12 used for surface visualization of the complex. Discovery Studio 2017 R2 Client was used for analysis of interaction of the receptor-ligand complex. 


\section{Statistical analysis}

Statistical analyses were performed using GraphPad Prism 6.0. The analysis of variance was performed on three independent cytotoxicity results by one way ANOVA analysis using tukey as post test. The results were considered significant at $\mathrm{p}$ value $<0.05$. The data were expressed as mean \pm SD.

\section{RESULTS}

Based on the selectivity of different extracts ${ }^{28}$, the plant leaf extract was selected for this study, as it showed higher cytotoxicity in cancer (MCF-7) cells and less toxicity for normal (L929) cells (selectivity 7.84) among all four extracts i.e. root, bark, leaf and fruit (supplement Fig 1).

\section{Phytochemical constituents of active extract}

The ethyl acetate extract of $S$. anacardium leaves was analyzed by GC-MS and seventeen major compounds (table 1, supplement figure 2) were identified. Among these compounds, (E)octadec-9-enoic acid had highest peak area (11.30\%), followed by palmitic acid $(9.89 \%)$, (E)3,7,11,15-tetramethylhexadec-2-en-1-ol $\quad(8.77 \%), \quad$ methyl3-(3,5-di-tert-butyl-4hydroxyphenyl)propanoate $(8.06 \%)$, and other phytochemicals were listed in the table 1. Compound 1 and 11 were alkaloids, compound 13, 14, 15 were steroids, compound 2 was terpenoids, compound 15, 16 were phenolic compound, compound 17 was flavonoid and remaining were aliphatic compounds.

\section{The extracts induce cytotoxicity in cancer cells.}

In this study, total six cell lines MCF7, MDA-MB-231, HCT-15, MIN6, EAC and L929 have been used to evaluate the anticancer activity of leaf extracts of Semecarpus anacardium Linn. in different organic solvents, petroleum ether, ethyl acetate and methanol which were coded as BLPE, BLEA and BLM respectively. The cells were treated with different concentration of the extracts, ranging from 0 to $200 \mu \mathrm{g} / \mathrm{ml}$, which induced cytotoxicity significantly in dose-depended manner as evaluated by MTT assay (fig. 1).

BLEA showed the most active extract and induced cytotoxicity among all cancer cell lines (supplementary table 1), MCF-7 and EAC cells exhibited the highest sensitivity with an $\mathrm{IC}_{50}$ of 0.57 and $1.71 \mu \mathrm{g} / \mathrm{ml}$ respectively, whereas, HCT-15, MIN-6 and HepG2 cells showed least sensitivity with an $\mathrm{IC}_{50}$ of $6.66,15.77$ and $44.93 \mu \mathrm{g} / \mathrm{ml}$ respectively towards the extracts (fig. 1). Although, BLEA showed very low cytotoxicity in normal L929 cells ( IC $_{50}$ value $29.62 \mu \mathrm{g} / \mathrm{ml}$ ) which indicated that the extracts were safe for normal cells. Based on the selectivity indices of the extracts in different cell lines, extract BLEA was selected against MCF-7 cells for further studies (supplement table 1). The cytotoxicity of BLEA was compared with paclitaxel in MCF-7 
cells which showed paclitaxel significantly affect the cells at very low concentration compare to BLEA (supplement fig. 3) as BLEA is a fraction of crude extract.

\section{BLEA alters cell morphology}

After the treatment of cells with BLEA, it is necessary to know, how the cells behave. For this purpose, BLEA treated MVF-7 cells were examined through light microscope which showed the cytoplasmic vacuolization in the treated cells. There was no cytoplasmic vacuolization in untreated cells. This result shows the drug have ability to induce stress in treated cancer cells. The details are shown in figures (fig. 2A-C).

\section{BLEA induces apoptosis}

BLEA induced cytotoxicity through altering cellular morphology and intracellular vacuolizations. So, to know the cell death mode, stained with DAPI staining and the cells were examined under fluorescence microscopy which revealed a significantly alteration in the morphology of nucleus in treated group of cells, such as chromatin condensation, nuclear fragmentation and shrunken nuclear morphology, were observed (fig. D-F). The untreated cells showed intact nuclear morphology. This result also supports apoptosis as a mode of cell death. Along with the above results, the cells were treated with BLEA at same concentration and apoptosis assay was performed using Ethidium bromide-Acridine orange double staining medoth. MCF-7 cells were treated with BLEA at $0.57 \mu \mathrm{g} / \mathrm{ml}$ concentrations (equivalence $\mathrm{IC}_{50}$ ) for $48 \square \mathrm{h}$, then stained with Ethidium bromide and Acridine orange which showed that the death induced in MCF-7 cells by BLEA was apoptosis, as the nuclear fragmentation, nuclear contraction, cytoplasmic membrane blebbing, entry of ethidium bromide into the cells, leading orange to red color fluorescence in cells were observed (fig. 2G-I).

\section{BLEA induces cell cycle arrest}

As cells were died through apoptosis when treated with BLEA, the effect of BLEA on cell cycle alteration was studied. BLEA was found to modestly increase the population of cells at the G1 phase. Furthermore, the sub G1 population of cells was also modestly increased at the higher concentration of BLEA $(500 \mathrm{ng} / \mathrm{ml})$. Conversely, the percentage of cells in the $\mathrm{S}$ and $\mathrm{G} 2 / \mathrm{M}$ phase was decreased with an increase of BLEA concentration (fig 2J-L). Overall, these observations suggest thatBLEA induces cell cycle arrest at the sub-G1 and G1 phases.

\section{BLEA inhibits cellular migration}

Cellular migration is one of the important characteristics of cancer cells which enables them to metastasis. To examine the effect of BLEA on cellular migration, the scratched wound created and treated with BLEA. The cells were examined on the day $1^{\text {st }}, 3^{\text {rd }}$ and $5^{\text {th }}$ for the healing of wound and found that BLEA decreases the cellular migration significantly, resulting delayed in wound healing (fig. 3).

\section{BLEA safe for oral administration in mice}


The toxicity of BLEA for oral administration was evaluated by oral acute toxicity with the standard protocol (test number 425 of OECD) in mice. The BLEA did not show any sign of toxicity even at high dose in mice. The tissues of vital organs were further analyzed for any cellular architectural alteration due to toxicity which did also not show any sign of toxicity. Interestingly, there was no any body weight loss was recorded in the animal treated with BLEA, which indicates that BLEA is non-toxic to the animals for oral administration (supplementary table 2 and supplement fig. 4).

\section{BLEA inhibits of tumor progression in mice}

The anticancer potency of BLEA was evaluated using EAC (Ehrlich ascites carcinoma) cells induced mice tumor model. Based on a pilot study (Supplementary fig. 5), $100 \mathrm{mg} / \mathrm{kg} \mathrm{b.wt.} \mathrm{dose}$ of BLEA was selected for evaluation of anti-tumor activity. The treatment of tumor-bearing mice was started from $8^{\text {th }}$ day of EAC cells injection, when tumors became measurable, with a daily dose of $100 \square \mathrm{mg} / \mathrm{kg}$ b.wt of BLEA with feeding needle till $28^{\text {th }}$ day. The volume of tumors was measured on alternative days. The oral administration of BLEA resulted in a significant $(\mathrm{p} \leq 0.05)$ decrease in tumor volume upon the treatment with BLEA, whereas the tumor volume was continuously increasing in control group of tumor-bearing mice (fig. 4A).

The mean volume of tumor observed on the day $8^{\text {th }}, 18^{\text {th }}$ and $28^{\text {th }}$ were $58.67,388.98$ and $780.44 \square \mathrm{mm}^{3}$ respectively in untreated tumor-bering control group of mice, whereas BLEA treatment reduced the tumor volume and found $58.67,224.00$ and $298.67 \square \mathrm{mm}^{3}$ respectively as compare to the control (fig. 4B-D). The histological examination of tissues from thigh, liver and spleen from tumor-bearing control group of mice showed alterations in cellular morphology compared to the treated and normal mice (fig. 4F-H). There were dead cells seen in tumor tissue of treated mice. Therefore, the study suggests that BLEA has potency to reduce tumor progression significantly in mice models.

\section{BLEA delays tumor associated death and enhances the survival of tumor bearing mice}

Importantly, this study showed that the tumor associated death in mice was delayed and first death in BLEA treated mice was recorded on the day $49^{\text {th }}$ whereas the first death in control tumor bearing mice was on the day $22^{\text {nd }}$. It was observed that about $50 \%$ survival in tumor bearing mice treated with BLEA was increased as compare to the control group of tumor bearing mice. The control untreated tumor bearing mice survived only upto 73 days after EAC injection, whereas the BLEA treated tumor bearing mice were survived more than 110 days. These results show the anticancer potential of BLEA which caused tumor growth regression as well as increased survival with the delay in tumor associated death in tumor bearing mice model. Further, the histological examination of dissected tumor tissues was done using haematoxylin-eosin double staining to explore the mechanism lying behind the tumor growth in tumor bearing mice models. The study showed a significant decrease in number of EAC cells in the tissue of thigh tumor of the mice received BLEA orally in comparison of untreated controls tumor bearing mice (fig. 4E). 


\section{Compounds of BLEA inhibit CDK2}

342

343

344

345

346

347

348

349

350

351

352

353

354

355

356

357

358

359

360

361

362

363

364

365

366

367

368

369

370

371

372

373

374

375

376

377

378

379

All 17 compounds of BLEA extract were found to have zero violation of Lipinski rule, which was suggested the possibility of the compound to be drug candidate with good bioavailability (data not shown). Compound 14 was bound to CDK2 with lowest Gibbs free energy, forming hydrogen bond with amino acid residues of CDK2 side chain such as Ile10, Thr14, Val18, Leu134, Ala144 and Asp145, while other closely interacting residues were Gly11, Glu12, Gly13, Tyr15, Lys33, His84, Gln85, Asp86, Lys89, Asp127, Lys129, Gln131 and Asn132 with a pocket area of $760.10 \AA^{2}$. The binding affinity of compound 13 was highest after compound 14, followed by compound 12 and 10 with $-45.27,-41.94$ and $-40.75 \mathrm{kcal} / \mathrm{mol}$ respectively. Compound 13 was found to interact with amino acid residues Ile10, Tyr15, Val18, Lys89, Leu134 and Ala144 through hydrogen bond directly, while closely interacting residues were Gly11, Glu12, Gly13, Thr14, Lys33, Gln85, Asp86, Asp127, Lys129, Gln131, Asn132 and Asp145 with a pocket area of $693.30 \AA^{2}$. Similarly, other compounds were found to have inhibitory action against CDK2 protein with different affinities and pocket areas, as showed in the table 2 and figure 5.

Overall, our results showed that BLEA induced cytotoxicity by inducing apoptosis, inhibited tumor growth, delayed the tumor associated death leading to significant increase in the survival of tumor bearing mice model. Thus, this study suggests that BLEA could be served as a prime source for development of chemotherapeutic agent for human cancer prevention.

\section{DISCUSSION}

The development of chemoresistance among cancer cells is major obstacle in its treatment, leading to high mortality rate in cancer patients. The drug inactivation, drug target alteration and drug efflux are influencing the chemoresistance development for existing target specific single molecule drug ${ }^{2}$. Therefore, plant extract or fractions which are mixture of multi-targeted compounds, having antitumor activity are potent tools to overcome the drug resistance. Traditionally used medicinal plants serve as the prime source for development of chemotherapeutic drugs with minimal side effect which also reduce the time and cost to develop potential chemotherapeutic agents.

Semecarpus anacardium Linn. is well known medicinal plant, its fruit is described in Ayurveda for preparation of several polyherbal formulations to treat clinical ailments such as inflammation, neurological problem, geriatric problem, vitiligo, cardiac troubles, enlargement of spleen, hemorrhoids, rheumatism, diabetes, baldness, etc including cancer ${ }^{29}$. S. anacardium nut extract has potency to regulate the key enzymes involved in carbohydrate metabolism which is elevated in cancer cells during tumor growth progression to enhance the synthesis of nucleic acid and lipids ${ }^{30}$ and cellular respiration ${ }^{31}$. It also maintains normal physiological level of cyto-protective Glutathione enzyme ${ }^{32}$, modulates tumor hypoxia associated factors ${ }^{33}$ and extracellular matrix associated enzymes ${ }^{29}$, leading to inhibition of tumor progression and metastasis in DMBA induced tumor bearing rats. The milk of nut has reported to have anticancer property in hepatocellular carcinoma in wistar rats ${ }^{34}$. The nut extract is cytotoxic and induced cell death 
through apoptosis in breast cancer (T47D) cells by arresting the treated cells in G2/M phase ${ }^{35}$. The compounds isolated from its nuts, show cytotoxicity with an IC50 value range from $0.10-$ $5.9 \mu \mathrm{g} / \mathrm{ml}$ among various cancer cell lines, 3-O-methyl quercetin and kaemeferol, show cytoprotective property against free radical induced cellular damage, the isolated compounds also shows synergistic effect with conventional drugs such as doxorobocin and induce apoptosis via arresting cells in G2/M phase of cell cycle in cancer cells ${ }^{15,36}$.

In this study, anticancer properties of $S$. anacardium leaves was investigated, which is an alternative source of phytochemicals and could be used for therapeutic purposes. The medicinal application of leaves remain unknown till the date. Here, the leaf extracts in three different organic solvents were prepared and evaluated first time for anticancer activity using various cell lines and animal tumor model. The ethyl acetate extract was found more potent cytotoxic against different cancer cell lines and induces apoptosis in MCF-7 cells. However, it was found fairly safe for normal (L929) cells. Moreover, the treatment of MCF-7 cells with BLEA exhibited cell cycle arrested in G1 phase and apoptotic cell death. The in vivo study using mice as animal model also exhibited that BLEA is safe for oral administration and potent for tumor growth inhibition. The extract delays the tumor related death and enhance the survival of tumor bearing mice.

The $\mathrm{IC}_{50}$ values of the leaves extracts shows different range for all three extracts, i.e. the range $1.33-8.65 \mu \mathrm{g} / \mathrm{ml}$ for petroleum ether, $0.57-15.77 \mu \mathrm{g} / \mathrm{ml}$ for ethyl acetate and $0.97-43.66 \mu \mathrm{g} / \mathrm{ml}$ for methanol in various cancer cells respectively which is slightly more than the compounds isolated from the nuts ${ }^{15}$. Moreover, the $\mathrm{IC}_{50}$ values of all three extracts of nuts are 32.73, 29.62 and $17.45 \mu \mathrm{g} / \mathrm{ml}$ for petroleum ether, ethyl acetate and methanol respectively which are also higher than the previous studies ${ }^{15}$. The selectivity index is an important tool in bioassay guided fractionation for selection of the best extract/fraction which indicate cytotoxicity to cancer cells and safety for normal cells ${ }^{28}$. The selectivity index is range from 0.40 to 52.17 for all three extract in different cancer cells. Among these, the selectivity index of ethyl acetate extract of the leaf is higher in human breast carcinoma (MCF-7) cells, resulting the selection of BLEA and MCF-7 cells for further studies.

The discovery and development of anticancer chemotherapeutic agents focuses on mode of cell death induced and their effect on cell cycle ${ }^{37}$. As apoptotic cell death is highly organized and programmed process. The drugs with apoptosis inducing property and inhibiting the tumor progression in cancer, are considered as novel anticancer chemotherapeutic drugs ${ }^{38}$. There are several cytoplasmic vacuoles induced after treatment with BLEA in breast cancer (MCF-7) cells which indicating the induction of apoptosis like cell death ${ }^{39,40}$. Double staing with AO-EtBr, followed by fluorescence microscopy for detection mode of cell death and differentiation of untreated cells, early apoptotic cells, late apoptotic cells and necrotic cells are indicating BLEA induced apoptosis in MCF-7 cells. As Acridine orange permeable to the unbroken plasma membrane and has ability to bind DNA, resulting green fluorescence, whereas Ethidium bromide 
enters inside the cells only broken plasma membrane, binds the nucleic acid ladder and emits red fluorescence. The fluorescing color green, yellowish orange, orange and red represent normal, early apoptotic, apoptotic and late apoptotic/necrotic cell death respectively ${ }^{41}$. The altered morphology was seen in the cells treated with BLEA and stained with DAPI stain, which further confirmed the apoptosis mode of cell death induction ${ }^{41}$. The cell cycle is series of events, regulated by various molecular signals at different checkpoints, resulting synthesis of DNA and division of cell into daughter cells. BLEA alters the cell cycle and arrests the MCF-7 cells at G1 phase. Interestingly, the nut extract has reported for arresting the cells at G2/M phase ${ }^{35}$. The above findings suggest that the molecular mode of action of nut extract and leaf extract are different in cancer cells ${ }^{42}$. The scratched wound assay is an important tool for study of cell migration as well as metastasis. Numerous phytochemicals and herbal extract have been reported for inhibition of cellular migration which may play an important role in prevention of metastasis in cancer patients ${ }^{43-45}$. The leaf extract, BLEA has also showed inhibition of cellular migration of MCF-7 cells in this study.

The progression of cell cycle through G1 phase depends on CDK2-Cyclin E complex ${ }^{46}$. The genotoxic stress induces cell cycle arrest with the help of CDK inhibitors such as $\mathrm{P}^{21}, \mathrm{P}^{27}, \mathrm{P}^{57}$, etc. The CDK inhibitors bind to $\mathrm{CDK}$, as a result the function of CDK-Cyclin complex is ceased. Similarly, the binding of $\mathrm{P}^{21}$ to $\mathrm{CDK} 2$ causes cells arrest in $\mathrm{G} 1$ phase of cell cycle ${ }^{46}$. Therefore, CDK2 inhibitor phytochemicals may be implemented as an efficient G1 phase arrest in treatment of cancer cells. Numerous phytochemicals are reported to have CDK2 inhibitory activity such as Artocarpin, Curcumin, Piperine, Urosolic Acid, etc ${ }^{47}$. All identified compounds were showed binding affinity to the target protein (CDK2), whereas compound 10,12, 13, 14 were showed strong binding affinity to the active site of CDK2 protein. The compounds of the potent extract BLEA, which have higher affinity to the target protein CDK2, also showed strong hydrogen bonding with the conserved amino acid residues such as Val18 and Leu134 as shown in table X and figure $\mathrm{Y}$. The molecular docking studies shows that the compounds of BLEA are capable to bind to the active site of CDK2, inhibit the binding of CDK2 to cyclin E, resulting arrest of cell cycle progression in G1 phase. The interaction of compounds with CDK2 shows possible cause of cell cycle arrest in G1 phase of cancer cells.

The different extracts of Semecarpus anacardium nuts are well known for their toxicity in human and animals ${ }^{17,48,49}$. The purification processes are described in Ayurveda to reduce its toxicity of nuts before clinical use ${ }^{50}$. However, in this study it has found that the ethyl acetate extract of leaf is safe for oral administration. There was no any morphological, physiological or behavioral sign of toxicity sign as well as death occurred in mice even received high dose (5000 mg/kg b. wt.) of the extract (BLEA). Interestingly, haematoxylin and eosin stained histological examination of stomach, liver, kidney and lung tissues did not show any alteration in cellular architecture in treated group of animals. 
The study has further extended to evaluate in vivo anti-tumor activity in EAC cells induced mice tumor model. The EAC cells are mouse derived ascetic carcinoma cells which easily accepted in mice body with high transplantable efficacy, rapid growth and confirmed malignancy. The subcutaneous injection of EAC cells, results the development of solid tumor model in mice, which is selected in this study ${ }^{51,52}$. BLEA has evaluated for anti-tumor potency using EAC induced allograft tumor mice model, which showed significant inhibition of tumor growth progression, delayed the tumor associated death and increase the survival of tumor bearing treated mice. These results are similar to the previously reported results of other herbal extracts such as extracts of Achras sapota, Vernonia condensate, Eclipta alba, etc ${ }^{2,24,53}$. Moreover, the examination of histological slide of tumor tissue stained with hematoxylin and eosin showed the death of tumor cells, induced by BLEA ${ }^{53}$.

\section{Conclusion}

The study explored the possibility of leaf extract as a prime source for anticancer phytochemicals with minimal toxicity, as it induces cytotoxicity in various cancer cell lines via cell cycle arrest, leading to apoptosis and safe for normal cells. Moreover, BLEA inhibited the tumor growth progression, delayed the death and enhanced survival significantly in tumor bearing mice model. Therefore, BLEA is potential extract for anticancer chemotherapy development. However, additional advanced studies are necessary for further development and elucidation of molecular pathways involved to develop a new drug.

\section{Acknowledgement}

We are thankful to Professor-in-charge, Centre of Experimental Medicine \& Surgery (CEMS), Institute of Medical Sciences, Banaras Hindu University, Varanasi, India for instrument facilities. RKS is grateful to BHU and UGC for financial supports as fellowship.

\section{Author Contributions}

RKS, AKS and AKS designed the study; RKS performed the experiments; SSV and SCG helped in cellcycle analysis; RKS, AR, RT, VS, AKS and AKS contributed to the formatting, writing and critical reviewing of the manuscript. All authors have read and approved the manuscript for publication.

\section{Conflict of interest}

All authors have declared for no conflicts of interest.

\section{References}

1. Lam F, Ervik M, Ferlay J, Soerjomataram I, Mery L, B. F. World Source: Globocan 2018. 876, 1-2 (2018).

2. Arya, R. K. et al. Anti-breast tumor activity of Eclipta extract in-vitro and in-vivo: novel evidence of endoplasmic reticulum specific localization of Hsp60 during apoptosis. Sci. 
Rep. 5, 18457 (2015).

491

492

493

494

495

496

497

498

499

500

501

502

503

504

505

506

507

508

509

510

511

512

513

514

515

516

517

518

519

520

521

522

523

524

525

526
3. Vijayalakshmi, T., Muthulakshmi, V.\& Sachdanandam, P. Effect of milk extract of Semecarpus anacardium nuts on glycohydrolases and lysosomal stability in adjuvant arthritis in rats. J. Ethnopharmacol. 58, 1-8 (1997).

4. Vijayalakshmi, T., Muthulakshmi, V.\& Sachdanandam, P. Toxic studies on biochemical parameters carried out in rats with Serankottai nei, a siddha drug-milk extract of Semecarpus anacardium nut. J. Ethnopharmacol. 69, 9-15 (2000).

5. Kim, J. H., Kismali, G. \& Gupta, S. C. Natural Products for the Prevention and Treatment of Chronic Inflammatory Diseases: Integrating Traditional Medicine into Modern Chronic Diseases Care. Evidence-based complementary and alternative medicine $\square$ : eCAM 2018, 9837863 (2018).

6. Joshi, K., Ghodke, Y. \& Shintre, P. Traditional medicine and genomics. J. Ayurveda Integr. Med. 1, 26-32 (2010).

7. Patwardhan, B. \& Vaidya, A. D. B. Natural products drug discovery: accelerating the clinical candidate development using reverse pharmacology approaches. Indian J. Exp. Biol. 48, 220-227 (2010).

8. Awasthee, N. et al. Anti-cancer activities of Bharangin against breast cancer: Evidence for the role of NF-kB and lncRNAs. Biochim. Biophys. Acta - Gen. Subj. 1862, 2738-2749 (2018).

9. Gupta, S. C., Prasad, S., Tyagi, A. K., Kunnumakkara, A. B. \& Aggarwal, B. B. Neem (Azadirachta indica): An indian traditional panacea with modern molecular basis. Phytomedicine 34, 14-20 (2017).

10. Pandey, M. K., Gupta, S. C., Nabavizadeh, A. \& Aggarwal, B. B. Regulation of cell signaling pathways by dietary agents for cancer prevention and treatment. Semin. Cancer Biol. 46, 158-181 (2017).

11. Mathivadhani, P., Shanthi, P. \& Sachdanandam, P. Effect of Semecarpus anacardium Linn. nut extract on mammary and hepatic expression of xenobiotic enzymes in DMBAinduced mammary carcinoma. Environ. Toxicol. Pharmacol. 23, 328-334 (2007).

12. Semalty, M., Semalty, A., Badola, A., Joshi, G. P. \& Rawat, M. S. M. Semecarpus anacardium Linn.: A review. Pharmacognosy Reviews 4, 88-94 (2010).

13. Sharma, A., Mathur, R. \& Dixit, V. P. Hypocholesterolemic activity of nut shell extract of Semecarpus anacardium (Bhilawa) in cholesterol fed rabbits. Indian J. Exp. Biol. 33, 444448 (1995).

14. Selvam, C., Jachak, S. M. \& Bhutani, K. K. Cyclooxygenase inhibitory flavonoids from the stem bark of Semecarpus anacardium Linn. Phytother. Res. 18, 582-584 (2004).

15. Nair, P. K. R. et al. Isolation and characterization of an anticancer catechol compound from Semecarpus anacardium. J. Ethnopharmacol. 122, 450-456 (2009). 
16. Adhami, H. R. et al. Catechol alkenyls from Semecarpus anacardium: acetylcholinesterase inhibition and binding mode predictions. J. Ethnopharmacol. 139, 142-148 (2012).

17. Llanchezhian, R., Joseph C, R. \& Rabinarayan, A. Urushiol-induced contact dermatitis caused during Shodhana (purificatory measures) of Bhallataka (Semecarpus anacardium Linn.) fruit. Ауи 33, 270-273 (2012).

18. Singh, R. K. et al. Cytotoxic and apoptotic inducing activity of Amoora rohituka leaf extracts in human breast cancer cells. J. Ayurveda Integr. Med. (2019). doi:https://doi.org/10.1016/j.jaim.2018.12.005

19. Usharani, B. \& Vasudevan, N. Root Exudates of Cyperus alternifolius in Partial Hydroponic Condition under Heavy Metal Stress. Pharmacognosy Res. 9, 294-300 (2017).

20. Ibms, A. L. M. P. G., Ibms, A. L. M. P. G. \& Ibms, A. L. M. P. G. formulation ) and its anticancer activity in MCF-7 cell line In vitro antioxidant potential of Shemamruthaa ( a herbal formulation ) and its anticancer activity in MCF-7 cell line Nandhakumar Elumalai a , Purushothaman Ayyakkannu a, Shanthi Palanivelu b . (2015).

21. Fitriani, A., Ihsan, F. \& Hamdiyati, Y. Antibacteria Activity of Shewanella and Pseudomonas as Endophytic Bacteria from the Root of Ageratum conyzoides L . (2015).

22. Singh, M., Singh, R. K., Singh, S. K., Mahto, S. K. \& Misra, N. In vitro biocompatibility analysis of functionalized poly(vinyl chloride)/layered double hydroxide nanocomposites. RSC Adv. 8, 40611-40620 (2018).

23. Srivastava, M. et al. Sapodilla plum (Achras sapota) induces apoptosis in cancer cell lines and inhibits tumor progression in mice. Sci. Rep. 4, 6147 (2014).

24. Thomas, E., Gopalakrishnan, V., Somasagara, R. R., Choudhary, B. \& Raghavan, S. C. Extract of Vernonia condensata, Inhibits Tumor Progression and Improves Survival of Tumor-allograft Bearing Mouse. Sci. Rep. 6, 23255 (2016).

25. Daina, A., Michielin, O. \& Zoete, V. SwissADME $\square$ : a free web tool to evaluate pharmacokinetics, drug- likeness and medicinal chemistry friendliness of small molecules. Nat. Publ. Gr. 1-13 (2017). doi:10.1038/srep42717

26. Baell, J., Congreve, M., Leeson, P. \& Abad-Zapatero, C. Ask the experts: past, present and future of the rule of five. Future medicinal chemistry 5, 745-752 (2013).

27. Ronchi, V. P., Kim, E. D., Summa, C. M., Klein, J. M. \& Haas, A. L. In silico modeling of the cryptic E2 approximately ubiquitin-binding site of E6-associated protein (E6AP)/UBE3A reveals the mechanism of polyubiquitin chain assembly. J. Biol. Chem. 292, 18006-18023 (2017).

28. Mfotie Njoya, E., Munvera, A. M., Mkounga, P., Nkengfack, A. E. \& McGaw, L. J. Phytochemical analysis with free radical scavenging, nitric oxide inhibition and antiproliferative activity of Sarcocephalus pobeguinii extracts. BMC Complement. Altern. Med. 17, 199 (2017). 
29. Mathivadhani, P., Shanthi, P. \& Sachdanandam, P. Effect of Semecarpus anacardium nut extract on ECM and proteases in mammary carcinoma rats. Vascul. Pharmacol. 46, 419426 (2007).

30. Sujatha, V. \& Sachdanandam, P. Recuperative effect of Semecarpus anacardium linn. nut milk extract on carbohydrate metabolizing enzymes in experimental mammary carcinomabearing rats. Phytother. Res. 16 Suppl 1, S14-8 (2002).

31. Arathi, G. \& Sachdanandam, P. Therapeutic effect of Semecarpus anacardium Linn. nut milk extract on carbohydrate metabolizing and mitochondrial TCA cycle and respiratory chain enzymes in mammary carcinoma rats. J. Pharm. Pharmacol. 55, 1283-1290 (2003).

32. Mathivadhani, P., Shanthi, P. \& Sachdanandam, P. Effect of Semecarpus anacardium Linn. nut milk extract on glutathione and its associated enzymes in experimentally induced mammary carcinoma. J. Med. Food 9, 265-269 (2006).

33. Mathivadhani, P., Shanthi, P. \& Sachdanandam, P. Hypoxia and its downstream targets in DMBA induced mammary carcinoma: protective role of Semecarpus anacardium nut extract. Chem. Biol. Interact. 167, 31-40 (2007).

34. Joseph, J. P., Raval, S. K., Sadariya, K. A., Jhala, M. \& Kumar, P. Anti cancerous efficacy of Ayurvedic milk extract of Semecarpus anacardium nuts on hepatocellular carcinoma in Wistar rats. African J. Tradit. Complement. Altern. Med. AJTCAM 10, 299-304 (2013).

35. Mathivadhani, P., Shanthi, P. \& Sachdanandam, P. Apoptotic effect of Semecarpus anacardium nut extract on T47D breast cancer cell line. Cell Biol. Int. 31, 1198-1206 (2007).

36. Kumar, A. D. N., Bevara, G. B., Kaja, L. K., Badana, A. K. \& Malla, R. R. Protective effect of 3-O-methyl quercetin and kaempferol from Semecarpus anacardium against $\mathrm{H} 2 \mathrm{O} 2$ induced cytotoxicity in lung and liver cells. BMC Complement. Altern. Med. 16, 376 (2016).

37. Hanahan, D. \& Weinberg, R. A. Hallmarks of cancer: the next generation. Cell 144, 646674 (2011).

38. Singh, S., Sharma, B., Kanwar, S. S. \& Kumar, A. Lead Phytochemicals for Anticancer Drug Development. Front. Plant Sci. 7, 1667 (2016).

39. Vijayarathna, S., Chen, Y., Kanwar, J. R. \& Sasidharan, S. Standardized Polyalthia longifolia leaf extract (PLME) inhibits cell proliferation and promotes apoptosis: The anticancer study with various microscopy methods. Biomed. Pharmacother. 91, 366-377 (2017).

40. Mallick, N. et al. HPTLC Analysis of Bioactivity Guided Anticancer Enriched Fraction of Hydroalcoholic Extract of Picrorhiza kurroa. 2015, (2015).

41. Ramya, P. V. S. et al. Synthesis and biological evaluation of curcumin inspired imidazo[1,2-a]pyridine analogues as tubulin polymerization inhibitors. Eur. J. Med. Chem. 143, 216-231 (2018). 
42. Krishnan, P. et al. Efficiency of newly formulated camptothecin with beta-cyclodextrinEDTA-Fe3O4 nanoparticle-conjugated nanocarriers as an anti-colon cancer (HT29) drug. Sci. Rep. 7, 10962 (2017).

43. Gao, L. et al. Uncovering the anticancer mechanism of Compound Kushen Injection against $\mathrm{HCC}$ by integrating quantitative analysis, network analysis and experimental validation. Sci. Rep. 8, 624 (2018).

44. Jiang, Z. et al. The traditional Chinese medicine Achyranthes bidentata and our de novo conception of its metastatic chemoprevention: from phytochemistry to pharmacology. Sci. Rep. 7, 3888 (2017).

45. Liang, F. et al. Kaempferol Identified by Zebrafish Assay and Fine Fractionations Strategy from Dysosma versipellis Inhibits Angiogenesis through VEGF and FGF Pathways. Sci. Rep. 5, 14468 (2015).

46. Schulze-Gahmen, U. et al. Multiple modes of ligand recognition: crystal structures of cyclin-dependent protein kinase 2 in complex with ATP and two inhibitors, olomoucine and isopentenyladenine. Proteins 22, 378-391 (1995).

47. Lapenna, S. \& Giordano, A. Cell cycle kinases as therapeutic targets for cancer. Nat. Rev. Drug Discov. 8, 547-566 (2009).

48. Sundaram, R., Karuppaiah, M., Shanthi, P. \& Sachdanandam, P. Acute and sub acute studies of catechol derivatives from Semecarpus anacardium. Toxicol. reports 5, 231-239 (2018).

49. Patwardhan, B., Saraf, M. N. \& David, S. B. Toxicity of semecarpus anacardium extract. Anc. Sci. Life 8, 106-109 (1988).

50. Maurya, S. K. et al. Śodhana: An Ayurvedic process for detoxification and modification of therapeutic activities of poisonous medicinal plants. Ancient Science of Life 34, 188197 (2015).

51. Mishra, S. et al. Subcutaneous Ehrlich Ascites Carcinoma mice model for studying cancer-induced cardiomyopathy. Sci. Rep. 8, 5599 (2018).

52. Ezzat, S. M. et al. Anticancer potentiality of lignan rich fraction of six Flaxseed cultivars. Sci. Rep. 8, 544 (2018).

53. Srivastava, M. et al. Sapodilla plum (Achras sapota) induces apoptosis in cancer cell lines and inhibits tumor progression in mice. Sci. Rep. 4, 6147 (2014).

54. Sreeja, P. S. et al. Sphenodesme involucrata var. paniculata (C.B. Clarke) Munir.: Chemical characterization, anti-nociceptive and anti-inflammatory activities of methanol extract of leaves. J. Ethnopharmacol. 225, 71-80 (2018).

55. Amelo, W., Nagpal, P. \& Makonnen, E. Antiplasmodial activity of solvent fractions of methanolic root extract of Dodonaea angustifolia in Plasmodium berghei infected mice. BMC Complement. Altern. Med. 14, 462 (2014). 
640 56. Bhattacharjee, A., Basu, A., Biswas, J., Sen, T. \& Bhattacharya, S. Chemoprotective and chemosensitizing properties of selenium nanoparticle (Nano-Se) during adjuvant therapy with cyclophosphamide in tumor-bearing mice. Mol. Cell. Biochem. 424, 13-33 (2017).

643 


\section{SUPPLEMENTARY DATA}

\section{Supplementary methods Evaluation of the oral acute toxicity}

The evaluation of oral acute toxicity was carried out as per the Organization for Economical Cooperation and Development (OECD test 425) described procedure. Total 18 mice of either sex were divided into three groups ( 3 male $\& 3$ female in each group) randomly viz. experimental groups $1 \& 2$ and control group 3 respectively. A day before an experiment, animals were kept on fasting. Next day, the ethyl acetate extract was administered orally using a $16 \mathrm{G}$ oral round ball tip feeding curved needles to the mice of the experimental groups. A single dose of 2000 $\mathrm{mg} / \mathrm{kg}$ and $5000 \mathrm{mg} / \mathrm{kg}$ body weight were administrated among the mice of experimental group 1 and 2 respectively, while distilled water was administrated to the mice of control group. All mice were observed individually after first $30 \mathrm{~min}$ dosing, special attention was given during the first $4 \mathrm{~h}$ and followed up from $24 \mathrm{~h}$ to $14^{\text {th }}$ day of the dosing to collect signs and symptoms of toxicity ${ }^{54,55}$. The attention was paid to investigate the potential occurrence of tremors, convulsions, salivation, diarrhea, lethargy and drowsiness. Live weight of the animals was monitored on days 0,7 and 14 of the dosing as one of the toxicity parameters. At the end of the experiment, the animals were sacrificed by cervical dislocation of anaesthetised animals and the organs viz. brain, stomach, liver, spleen, lungs, kidneys, muscles, esophagus and small intestine were collected to evaluate histopathological changes.

\section{Tumor model development}

EAC cell induced tumor model was chosen for this study, as it is of mouse origin and can be easily transplanted in immunocompetent mouse. The EAC cells were harvested from $75 \mathrm{~cm}^{2}$ cell culture flask with $70-80 \%$ cell confluence by trypsinization and followed by centrifugation at $750 \mathrm{rpm}$ (Remi R8C) for $5 \mathrm{~min}$. The harvested cells were diluted in $10 \mathrm{mM}$ phosphate buffered saline (1X PBS) at a density of $5 \square \times \square 10^{6} \square$ cells, and $200 \mu$ l of viable cell solution were injected into the peritoneal cavity of each recipient mouse of $21 \pm 1 \mathrm{~g}$ body weight and allowed to multiply. The EAC cells were withdrawn from peritoneal cavity of the donor mice after 8-10 days of inoculation and diluted in 1X PBS and centrifuged at $750 \mathrm{rpm}$ (Remi R8C) for 5 minutes and the cell pellet was resuspended in sterile $10 \mathrm{mM}$ PBS which was injected $(100 \mu 1$ at $1 \square \times \square 10^{7} \square$ cells/ml) in left thigh of female mice for developing solid tumor ${ }^{51,56}$.

\section{Pilot study for effective dose determination}

After 4 days of EAC inoculation, a pilot study was set up for determination of effective dose in EAC induced tumor-bearing mice which were divided into four groups of 3 mice in each. The tumor-bearing mice were administered 200, 100 and $50 \mathrm{mg} / \mathrm{kg}$ body weight of ethyl extract of test drug in group 1, 2 and 3 respectively while $100 \mu$ distilled water was given to the mice of 
group 4 named as control once daily for 14 days ${ }^{53}$ along with normal diet and water ad libitum. At the end of $14^{\text {th }}$ days, the mice were sacrificed and tumors were dissected out for their volume calculation. Tumor size was measured by Vernier calipers using the formula $\mathrm{V}=0.5 \times \mathrm{a} \times \mathrm{b}^{2}$, where ' $a$ ' and ' $b$ ' indicates the major and minor diameter, respectively.

\section{Supplement table 1}

Selective index of different extracts against cancer cell lines.

\begin{tabular}{|l|c|c|c|c|c|c|}
\hline Selective Index & MCF-7 & MDA-231 & HCT-15 & MIN6 & EAC & L929 \\
\hline BLPE & 14.92 & 5.07 & 4.69 & 24.61 & 3.79 & 1.00 \\
\hline BLEA & $\mathbf{5 2 . 1 7}$ & 2.36 & 4.45 & 1.88 & 17.37 & 1.00 \\
\hline BLM & 17.96 & 3.13 & 1.11 & 0.40 & 1.36 & 1.00 \\
\hline
\end{tabular}




\section{Supplement table 2}

Observational study for BLEA oral toxicity in mice (OECD test 425).

\begin{tabular}{|c|c|c|c|c|c|c|c|c|c|c|c|c|c|c|}
\hline \multirow{2}{*}{ Observation } & \multicolumn{2}{|c|}{$0 \mathrm{~h}$} & \multicolumn{2}{|c|}{$0.5 \mathrm{~h}$} & \multicolumn{2}{|c|}{$1 \mathrm{~h}$} & \multicolumn{2}{|c|}{$2 \mathrm{~h}$} & \multicolumn{2}{|c|}{$4 \mathrm{~h}$} & \multicolumn{2}{|c|}{$24 \mathrm{~h}$} & \multicolumn{2}{|c|}{$14^{\text {th }}$ day } \\
\hline & D1 & D2 & D1 & D2 & D1 & D2 & $\overline{D 1}$ & D2 & $\overline{\text { D1 }}$ & D2 & D1 & D2 & D1 & $\overline{\mathrm{D} 2}$ \\
\hline Skin \& fur & $\mathrm{N}$ & $\mathrm{N}$ & $\mathrm{N}$ & $\mathrm{N}$ & $\mathrm{N}$ & $\mathrm{N}$ & $\mathrm{N}$ & $\mathrm{N}$ & $\mathrm{N}$ & $\mathrm{N}$ & $\mathrm{N}$ & $\mathrm{N}$ & $\mathrm{N}$ & $\mathrm{N}$ \\
\hline Mucous membrane & $\mathrm{N}$ & $\mathrm{N}$ & $\mathrm{N}$ & $\mathrm{N}$ & $\mathrm{N}$ & $\mathrm{N}$ & $\mathrm{N}$ & $\mathrm{N}$ & $\mathrm{N}$ & $\mathrm{N}$ & $\mathrm{N}$ & $\mathrm{N}$ & $\mathrm{N}$ & $\mathrm{N}$ \\
\hline Tremors & $\mathrm{N}$ & $\mathrm{N}$ & $\mathrm{N}$ & $\mathrm{N}$ & $\mathrm{N}$ & $\mathrm{N}$ & $\mathrm{N}$ & $\mathrm{N}$ & $\overline{\mathrm{N}}$ & $\mathrm{N}$ & $\mathrm{N}$ & $\mathrm{N}$ & $\mathrm{N}$ & $\mathrm{N}$ \\
\hline Convulsion & $\mathrm{N}$ & $\mathrm{N}$ & $\mathrm{N}$ & $\mathrm{N}$ & $\mathrm{N}$ & $\mathrm{N}$ & $\mathrm{N}$ & $\mathrm{N}$ & $\mathrm{N}$ & $\mathrm{N}$ & $\mathrm{N}$ & $\mathrm{N}$ & $\mathrm{N}$ & $\mathrm{N}$ \\
\hline Salivation & $\mathrm{N}$ & $\mathrm{N}$ & $\mathrm{N}$ & $\mathrm{N}$ & $\mathrm{N}$ & $\mathrm{N}$ & $\mathrm{N}$ & $\mathrm{N}$ & $\mathrm{N}$ & $\mathrm{N}$ & $\mathrm{N}$ & $\mathrm{N}$ & $\mathrm{N}$ & $\mathrm{N}$ \\
\hline Diarrhea & $\mathrm{N}$ & $\mathrm{N}$ & $\mathrm{N}$ & $\mathrm{N}$ & $\mathrm{N}$ & $\mathrm{N}$ & $\mathrm{N}$ & $\mathrm{N}$ & $\mathrm{N}$ & $\mathrm{N}$ & $\mathrm{N}$ & $\mathrm{N}$ & $\mathrm{N}$ & $\mathrm{N}$ \\
\hline Sleep & $\mathrm{N}$ & $\mathrm{N}$ & $\mathrm{N}$ & $\mathrm{N}$ & $\mathrm{Y}$ & $Y$ & $\mathrm{~N}$ & $Y$ & $\mathrm{~N}$ & $\mathrm{~N}$ & $\mathrm{~N}$ & $\mathrm{~N}$ & $\mathrm{~N}$ & $\mathrm{~N}$ \\
\hline Coma & $\mathrm{N}$ & $\mathrm{N}$ & $\mathrm{N}$ & $\mathrm{N}$ & $\mathrm{N}$ & $\mathrm{N}$ & $\mathrm{N}$ & $\mathrm{N}$ & $\overline{\mathrm{N}}$ & $\mathrm{N}$ & $\mathrm{N}$ & $\mathrm{N}$ & $\mathrm{N}$ & $\mathrm{N}$ \\
\hline Lethargy & $\mathrm{N}$ & $\mathrm{N}$ & $\mathrm{N}$ & $\mathrm{N}$ & $\mathrm{N}$ & $\mathrm{N}$ & $\mathrm{N}$ & $\mathrm{N}$ & $\mathrm{N}$ & $\mathrm{N}$ & $\mathrm{N}$ & $\mathrm{N}$ & $\mathrm{N}$ & $\mathrm{N}$ \\
\hline Mortality & $\mathrm{N}$ & $\mathrm{N}$ & $\mathrm{N}$ & $\mathrm{N}$ & $\mathrm{N}$ & $\mathrm{N}$ & $\mathrm{N}$ & $\mathrm{N}$ & $\mathrm{N}$ & $\mathrm{N}$ & $\mathrm{N}$ & $\mathrm{N}$ & $\mathrm{N}$ & $\mathrm{N}$ \\
\hline
\end{tabular}

\section{References}

1. Lam F, Ervik M, Ferlay J, Soerjomataram I, Mery L, B. F. World Source: Globocan 2018. 876, 1-2 (2018).

2. Arya, R. K. et al. Anti-breast tumor activity of Eclipta extract in-vitro and invivo: novel evidence of endoplasmic reticulum specific localization of Hsp60 during apoptosis. Sci. Rep. 5, 18457 (2015).

3. Vijayalakshmi, T., Muthulakshmi, V. \& Sachdanandam, P. Effect of milk extract of Semecarpus anacardium nuts on glycohydrolases and lysosomal stability in adjuvant arthritis in rats. J. Ethnopharmacol. 58, 1-8 (1997).

4. Vijayalakshmi, T., Muthulakshmi, V. \& Sachdanandam, P. Toxic studies on 
biochemical parameters carried out in rats with Serankottai nei, a siddha drug-milk extract of Semecarpus anacardium nut. J. Ethnopharmacol. 69, 915 (2000).

5. Kim, J. H., Kismali, G. \& Gupta, S. C. Natural Products for the Prevention and Treatment of Chronic Inflammatory Diseases: Integrating Traditional Medicine into Modern Chronic Diseases Care. Evidence-based complementary and alternative medicine $\square$ : eCAM 2018, 9837863 (2018).

6. Joshi, K., Ghodke, Y. \& Shintre, P. Traditional medicine and genomics. $J$. Ayurveda Integr. Med. 1, 26-32 (2010).

7. Patwardhan, B. \& Vaidya, A. D. B. Natural products drug discovery: accelerating the clinical candidate development using reverse pharmacology approaches. Indian J. Exp. Biol. 48, 220-227 (2010).

8. Awasthee, N. et al. Anti-cancer activities of Bharangin against breast cancer: Evidence for the role of NF- $\kappa \mathrm{B}$ and lncRNAs. Biochim. Biophys. Acta - Gen. Subj. 1862, 2738-2749 (2018).

9. Gupta, S. C., Prasad, S., Tyagi, A. K., Kunnumakkara, A. B. \& Aggarwal, B. B. Neem (Azadirachta indica): An indian traditional panacea with modern molecular basis. Phytomedicine 34, 14-20 (2017).

10. Pandey, M. K., Gupta, S. C., Nabavizadeh, A. \& Aggarwal, B. B. Regulation of cell signaling pathways by dietary agents for cancer prevention and treatment. Semin. Cancer Biol. 46, 158-181 (2017).

11. Mathivadhani, P., Shanthi, P. \& Sachdanandam, P. Effect of Semecarpus anacardium Linn. nut extract on mammary and hepatic expression of xenobiotic enzymes in DMBA-induced mammary carcinoma. Environ. Toxicol. Pharmacol. 23, 328-334 (2007).

12. Semalty, M., Semalty, A., Badola, A., Joshi, G. P. \& Rawat, M. S. M. Semecarpus anacardium Linn.: A review. Pharmacognosy Reviews 4, 88-94 (2010).

13. Sharma, A., Mathur, R. \& Dixit, V. P. Hypocholesterolemic activity of nut shell extract of Semecarpus anacardium (Bhilawa) in cholesterol fed rabbits. Indian J. Exp. Biol. 33, 444-448 (1995).

14. Selvam, C., Jachak, S. M. \& Bhutani, K. K. Cyclooxygenase inhibitory flavonoids from the stem bark of Semecarpus anacardium Linn. Phytother. Res. 18, 582-584 (2004). 
15. Nair, P. K. R. et al. Isolation and characterization of an anticancer catechol compound from Semecarpus anacardium. J. Ethnopharmacol. 122, 450-456 (2009).

16. Adhami, H. R. et al. Catechol alkenyls from Semecarpus anacardium: acetylcholinesterase inhibition and binding mode predictions. $J$. Ethnopharmacol. 139, 142-148 (2012).

17. Llanchezhian, R., Joseph C, R. \& Rabinarayan, A. Urushiol-induced contact dermatitis caused during Shodhana (purificatory measures) of Bhallataka (Semecarpus anacardium Linn.) fruit. Ауи 33, 270-273 (2012).

18. Singh, R. K. et al. Cytotoxic and apoptotic inducing activity of Amoora rohituka leaf extracts in human breast cancer cells. J. Ayurveda Integr. Med. (2019). doi:https://doi.org/10.1016/j.jaim.2018.12.005

19. Usharani, B. \& Vasudevan, N. Root Exudates of Cyperus alternifolius in Partial Hydroponic Condition under Heavy Metal Stress. Pharmacognosy Res. 9, 294-300 (2017).

20. Ibms, A. L. M. P. G., Ibms, A. L. M. P. G. \& Ibms, A. L. M. P. G. formulation ) and its anticancer activity in MCF-7 cell line In vitro antioxidant potential of Shemamruthaa ( a herbal formulation ) and its anticancer activity in MCF-7 cell line Nandhakumar Elumalai a, Purushothaman Ayyakkannu a, Shanthi Palanivelu b . (2015).

21. Fitriani, A., Ihsan, F. \& Hamdiyati, Y. Antibacteria Activity of Shewanella and Pseudomonas as Endophytic Bacteria from the Root of Ageratum conyzoides L . (2015).

22. Singh, M., Singh, R. K., Singh, S. K., Mahto, S. K. \& Misra, N. In vitro biocompatibility analysis of functionalized poly(vinyl chloride)/layered double hydroxide nanocomposites. RSC Adv. 8, 40611-40620 (2018).

23. Srivastava, M. et al. Sapodilla plum (Achras sapota) induces apoptosis in cancer cell lines and inhibits tumor progression in mice. Sci. Rep. 4, 6147 (2014).

24. Thomas, E., Gopalakrishnan, V., Somasagara, R. R., Choudhary, B. \& Raghavan, S. C. Extract of Vernonia condensata, Inhibits Tumor Progression and Improves Survival of Tumor-allograft Bearing Mouse. Sci. Rep. 6, 23255 (2016).

25. Daina, A., Michielin, O. \& Zoete, V. SwissADME $\square$ : a free web tool to 
evaluate pharmacokinetics, drug- likeness and medicinal chemistry friendliness of small molecules. Nat. Publ. Gr. 1-13 (2017). doi:10.1038/srep42717

26. Baell, J., Congreve, M., Leeson, P. \& Abad-Zapatero, C. Ask the experts: past, present and future of the rule of five. Future medicinal chemistry $\mathbf{5}$, 745-752 (2013).

27. Ronchi, V. P., Kim, E. D., Summa, C. M., Klein, J. M. \& Haas, A. L. In silico modeling of the cryptic E2 approximately ubiquitin-binding site of E6associated protein (E6AP)/UBE3A reveals the mechanism of polyubiquitin chain assembly. J. Biol. Chem. 292, 18006-18023 (2017).

28. Mfotie Njoya, E., Munvera, A. M., Mkounga, P., Nkengfack, A. E. \& McGaw, L. J. Phytochemical analysis with free radical scavenging, nitric oxide inhibition and antiproliferative activity of Sarcocephalus pobeguinii extracts. BMC Complement. Altern. Med. 17, 199 (2017).

29. Mathivadhani, P., Shanthi, P. \& Sachdanandam, P. Effect of Semecarpus anacardium nut extract on ECM and proteases in mammary carcinoma rats. Vascul. Pharmacol. 46, 419-426 (2007).

30. Sujatha, V. \& Sachdanandam, P. Recuperative effect of Semecarpus anacardium linn. nut milk extract on carbohydrate metabolizing enzymes in experimental mammary carcinoma-bearing rats. Phytother. Res. 16 Suppl 1, S14-8 (2002).

31. Arathi, G. \& Sachdanandam, P. Therapeutic effect of Semecarpus anacardium Linn. nut milk extract on carbohydrate metabolizing and mitochondrial TCA cycle and respiratory chain enzymes in mammary carcinoma rats. J. Pharm. Pharmacol. 55, 1283-1290 (2003).

32. Mathivadhani, P., Shanthi, P. \& Sachdanandam, P. Effect of Semecarpus anacardium Linn. nut milk extract on glutathione and its associated enzymes in experimentally induced mammary carcinoma. J. Med. Food 9, 265-269 (2006).

33. Mathivadhani, P., Shanthi, P. \& Sachdanandam, P. Hypoxia and its downstream targets in DMBA induced mammary carcinoma: protective role of Semecarpus anacardium nut extract. Chem. Biol. Interact. 167, 31-40 (2007).

34. Joseph, J. P., Raval, S. K., Sadariya, K. A., Jhala, M. \& Kumar, P. Anti 
cancerous efficacy of Ayurvedic milk extract of Semecarpus anacardium nuts on hepatocellular carcinoma in Wistar rats. African J. Tradit. Complement. Altern. Med. AJTCAM 10, 299-304 (2013).

35. Mathivadhani, P., Shanthi, P. \& Sachdanandam, P. Apoptotic effect of Semecarpus anacardium nut extract on T47D breast cancer cell line. Cell Biol. Int. 31, 1198-1206 (2007).

36. Kumar, A. D. N., Bevara, G. B., Kaja, L. K., Badana, A. K. \& Malla, R. R. Protective effect of 3-O-methyl quercetin and kaempferol from Semecarpus anacardium against $\mathrm{H} 2 \mathrm{O} 2$ induced cytotoxicity in lung and liver cells. BMC Complement. Altern. Med. 16, 376 (2016).

37. Hanahan, D. \& Weinberg, R. A. Hallmarks of cancer: the next generation. Cell 144, 646-674 (2011).

38. Singh, S., Sharma, B., Kanwar, S. S. \& Kumar, A. Lead Phytochemicals for Anticancer Drug Development. Front. Plant Sci. 7, 1667 (2016).

39. Vijayarathna, S., Chen, Y., Kanwar, J. R. \& Sasidharan, S. Standardized Polyalthia longifolia leaf extract (PLME) inhibits cell proliferation and promotes apoptosis: The anti-cancer study with various microscopy methods. Biomed. Pharmacother. 91, 366-377 (2017).

40. Mallick, N. et al. HPTLC Analysis of Bioactivity Guided Anticancer Enriched Fraction of Hydroalcoholic Extract of Picrorhiza kurroa. 2015, (2015).

41. Ramya, P. V. S. et al. Synthesis and biological evaluation of curcumin inspired imidazo[1,2-a]pyridine analogues as tubulin polymerization inhibitors. Eur. J. Med. Chem. 143, 216-231 (2018).

42. Krishnan, P. et al. Efficiency of newly formulated camptothecin with betacyclodextrin-EDTA-Fe3O4 nanoparticle-conjugated nanocarriers as an anticolon cancer (HT29) drug. Sci. Rep. 7, 10962 (2017).

43. Gao, L. et al. Uncovering the anticancer mechanism of Compound Kushen Injection against HCC by integrating quantitative analysis, network analysis and experimental validation. Sci. Rep. 8, 624 (2018).

44. Jiang, Z. et al. The traditional Chinese medicine Achyranthes bidentata and our de novo conception of its metastatic chemoprevention: from phytochemistry to pharmacology. Sci. Rep. 7, 3888 (2017). 
45. Liang, F. et al. Kaempferol Identified by Zebrafish Assay and Fine Fractionations Strategy from Dysosma versipellis Inhibits Angiogenesis through VEGF and FGF Pathways. Sci. Rep. 5, 14468 (2015).

46. Schulze-Gahmen, U. et al. Multiple modes of ligand recognition: crystal structures of cyclin-dependent protein kinase 2 in complex with ATP and two inhibitors, olomoucine and isopentenyladenine. Proteins 22, 378-391 (1995).

47. Lapenna, S. \& Giordano, A. Cell cycle kinases as therapeutic targets for cancer. Nat. Rev. Drug Discov. 8, 547-566 (2009).

48. Sundaram, R., Karuppaiah, M., Shanthi, P. \& Sachdanandam, P. Acute and sub acute studies of catechol derivatives from Semecarpus anacardium. Toxicol. reports 5, 231-239 (2018).

49. Patwardhan, B., Saraf, M. N. \& David, S. B. Toxicity of semecarpus anacardium extract. Anc. Sci. Life 8, 106-109 (1988).

50. Maurya, S. K. et al. Śodhana: An Ayurvedic process for detoxification and modification of therapeutic activities of poisonous medicinal plants. Ancient Science of Life 34, 188-197 (2015).

51. Mishra, S. et al. Subcutaneous Ehrlich Ascites Carcinoma mice model for studying cancer-induced cardiomyopathy. Sci. Rep. 8, 5599 (2018).

52. Ezzat, S. M. et al. Anticancer potentiality of lignan rich fraction of six Flaxseed cultivars. Sci. Rep. 8, 544 (2018).

53. Srivastava, M. et al. Sapodilla plum (Achras sapota) induces apoptosis in cancer cell lines and inhibits tumor progression in mice. Sci. Rep. 4, 6147 (2014).

54. Sreeja, P. S. et al. Sphenodesme involucrata var. paniculata (C.B. Clarke) Munir.: Chemical characterization, anti-nociceptive and anti-inflammatory activities of methanol extract of leaves. J. Ethnopharmacol. 225, 71-80 (2018).

55. Amelo, W., Nagpal, P. \& Makonnen, E. Antiplasmodial activity of solvent fractions of methanolic root extract of Dodonaea angustifolia in Plasmodium berghei infected mice. BMC Complement. Altern. Med. 14, 462 (2014).

56. Bhattacharjee, A., Basu, A., Biswas, J., Sen, T. \& Bhattacharya, S. Chemoprotective and chemosensitizing properties of selenium nanoparticle (Nano-Se) during adjuvant therapy with cyclophosphamide in tumor-bearing 
bioRxiv preprint doi: https://doi.org/10.1101/2020.01.08.898940; this version posted August 15, 2020. The copyright holder for this preprint (which was not certified by peer review) is the author/funder. All rights reserved. No reuse allowed without permission.

mice. Mol. Cell. Biochem. 424, 13-33 (2017). 


\section{CAPTIONS OF FIGURES}

Figure 1: Evaluation of cytotoxicity of different extracts on different cell lines. Different cell lines (A) Human breast cancer cells, MCF-7, (B) Human triple negative breast cancer cells, MDA-MB-231, (C) Human colorectal carcinoma cells, HCT-15, (D) Mouse insulinoma cells, MIN6, (E) Mouse ascetic carcinoma cells, EAC and (F) Mouse fibroblast cells, L929 treated with BLPE, BLEA \& BLM respectively and cytotoxicity was evaluated by MTT assay after 48 hours of treatment.

Figure 2: Effect of BLEA on cell morphology, death and cell cycle in MCF-7 cells. Light microscopy: Cellular vacuolization in cells treated with (A) Paclitaxel (2.13 ng/ml), (B) BLEA $(0.57 \mu \mathrm{g} / \mathrm{ml})$ and (C) control. Fluorescence microscopy: evaluation of nuclear morphology using DAPI staining in cells treated with (D) Paclitaxel $(2.13 \mathrm{ng} / \mathrm{ml})$, (E) BLEA $(0.57 \mu \mathrm{g} / \mathrm{ml})$ and $(\mathrm{F})$ control, and evaluation of cell death using Ethidium bromide-Acridine orange double staining in cells treated with (G) Paclitaxel $(2.13 \mathrm{ng} / \mathrm{ml})$, (H) BLEA $(0.57 \mu \mathrm{g} / \mathrm{ml})$ and (I) control. FACS analysis: The treated cells showed arrest of cell cycle in G1 phase dependent on concentration ( $\mathrm{J}$ ) control cells, (K) $0.10 \mu \mathrm{g} / \mathrm{ml}$ and $(\mathrm{L}) 0.20 \mu \mathrm{g} / \mathrm{ml}$.

Figure 3: BLEA inhibited the cellular migration in MCF-7 cells. The wound healing assay was used to examine the effect of BLEA on wound closure and cellular migration rate. 
Figure 4: Effect of BLEA on tumor progression, survival and cellular architecture of tumor in tumor bearing mice. Mouse origin EAC cells induced solid tumor was developed in left thigh of mice and $100 \mathrm{mg} / \mathrm{kg} \mathrm{b}$. wt. dose of BLEA was administered orally after eight days of EAC injection throughout the experimental period. (A) Effect of BLEA on tumor progression, (B) tumor of control group, (C) tumor of treated group, (D) thigh of normal mice, (E) survival curves (Kaplan-Meier) of treated and untreated tumor bearing mice, (F) section of untreated HE stained tumor, $(\mathrm{G})$ section of treated HE stained tumor and $(\mathrm{H})$ normal thigh section.

Figure 5: Visualization of the interaction of receptor protein, CDK2 with ligands molecules in which A represents 3D surface view of binding site of compounds, B represents 3D spatial interactions and $\mathrm{C}$ represents $2 \mathrm{D}$ interaction of the compounds respectively. 1-17 represents the compounds. 
Supplement figure 1: the cytotoxicity of root, bark, leave and fruits in cancer cells (MCF-7) and normal cells (L929).

Supplement figure 2: structure of the identified compounds.

Supplement figure 3: the cytotoxicity of PTX and BLEA in MCF-7 cells.

Supplement figure 4: Histological evaluation of toxicity of BLEA in different vital organs. HE staining was done to visualize the cellular architecture of different tissues of control and treated groups.

Supplement figure 5: Effective dose determination of BLEA using different doses (50, 100 and $200 \mathrm{mg} / \mathrm{kg} \mathrm{b}$. wt.) in comparison of control (pilot study). 
72 hrs

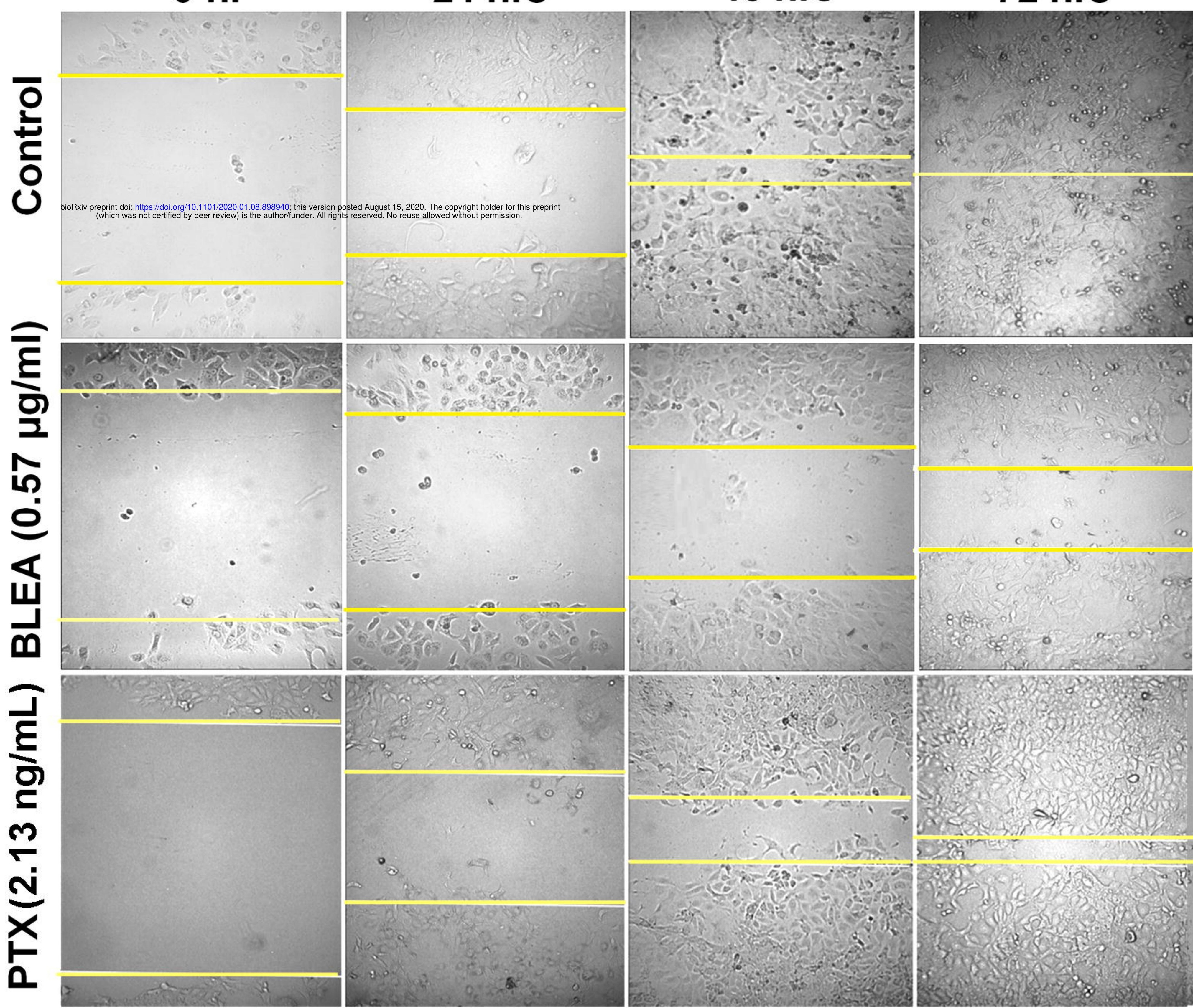




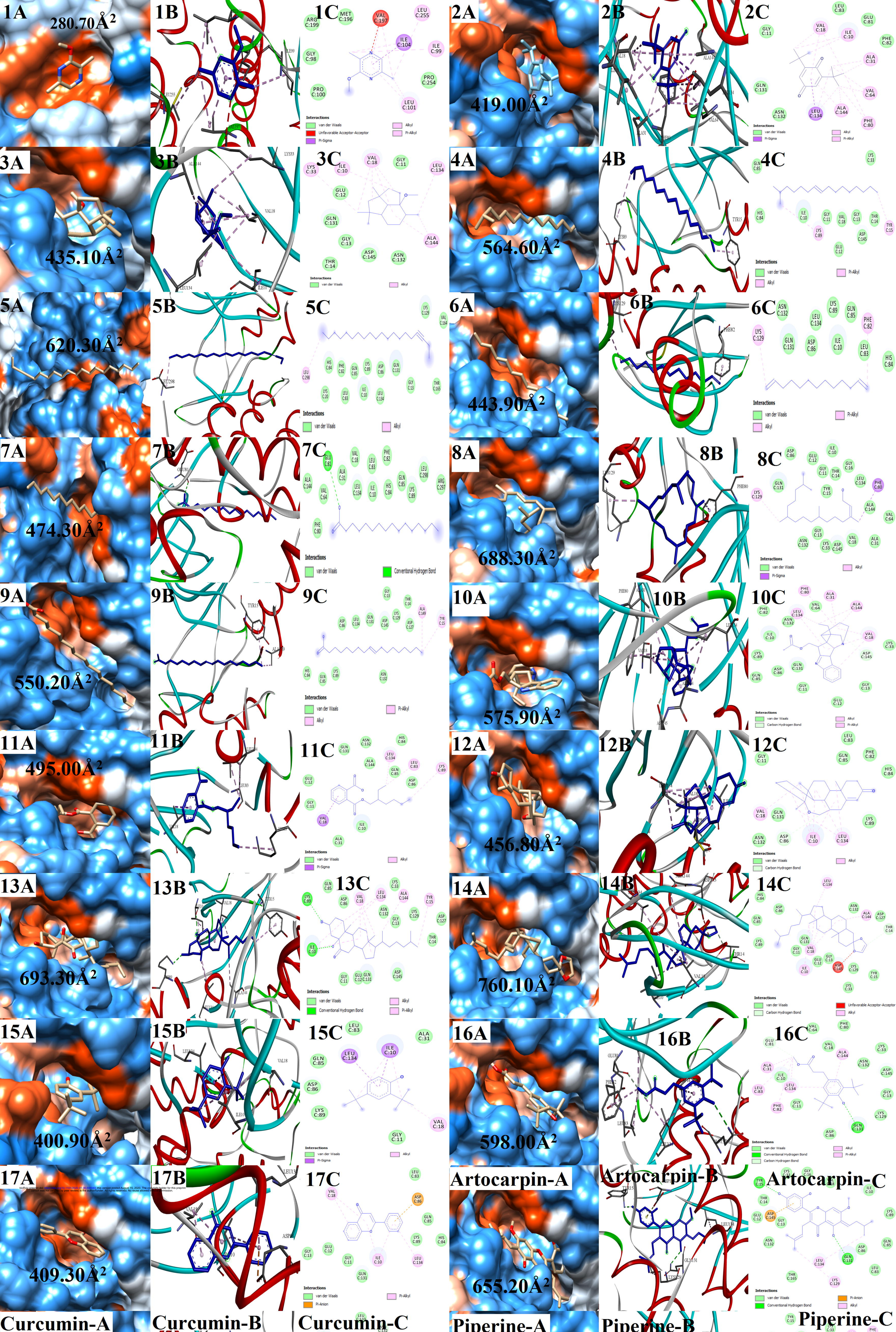

Curcumin-A Curcumin-B |Curcumin-C

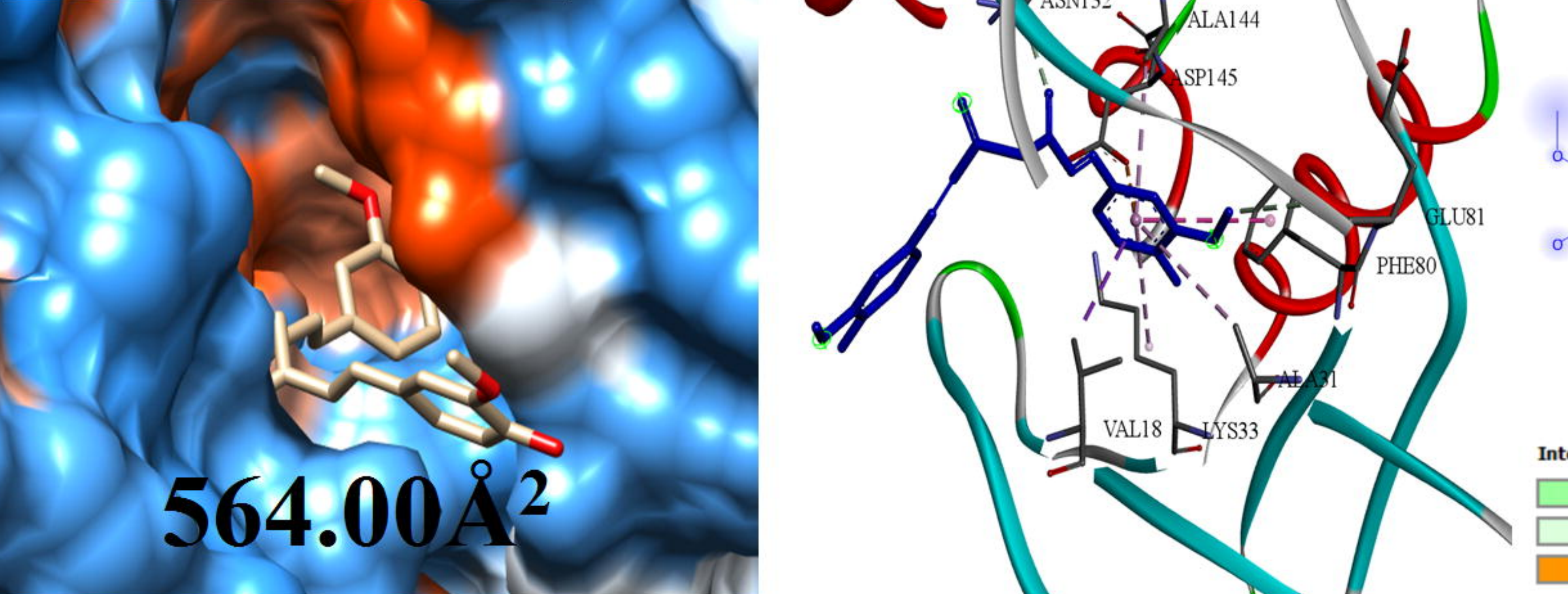

Piperine-A Pipeyne-B on Piperine-C

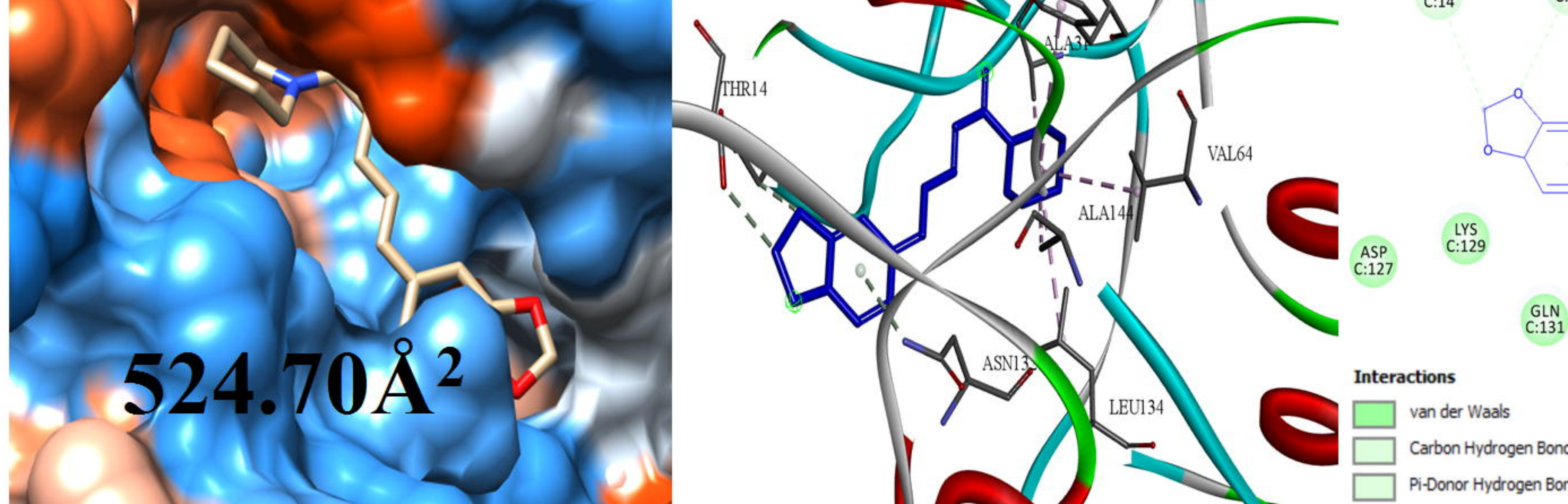




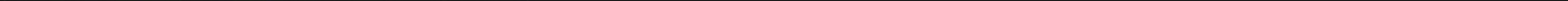




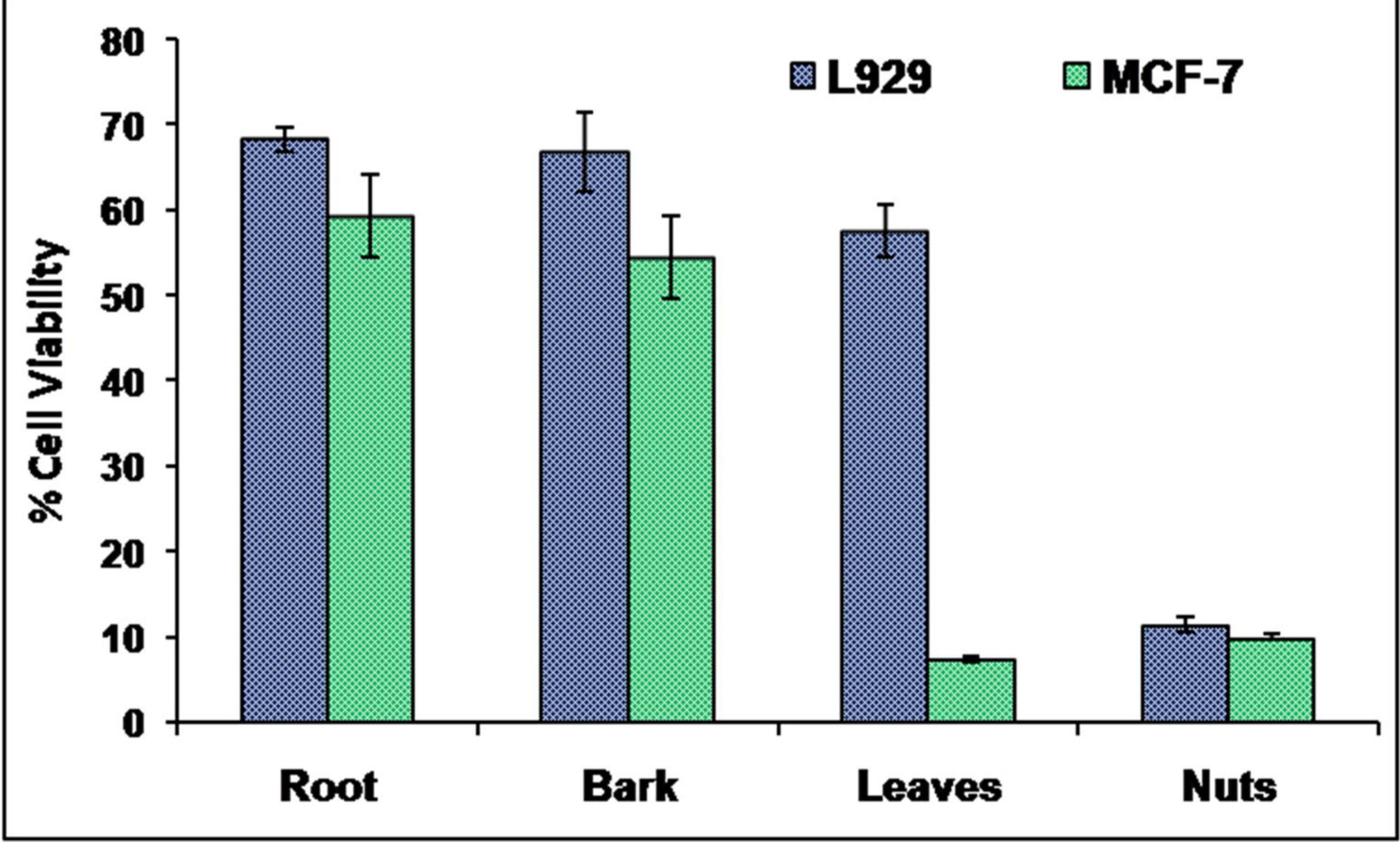




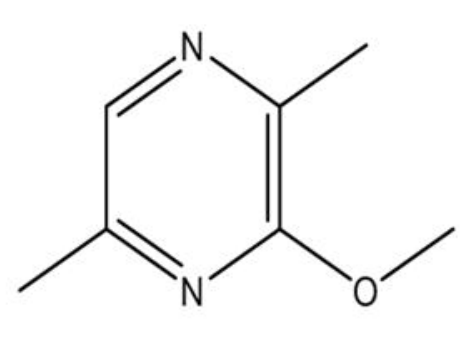

Compound 1

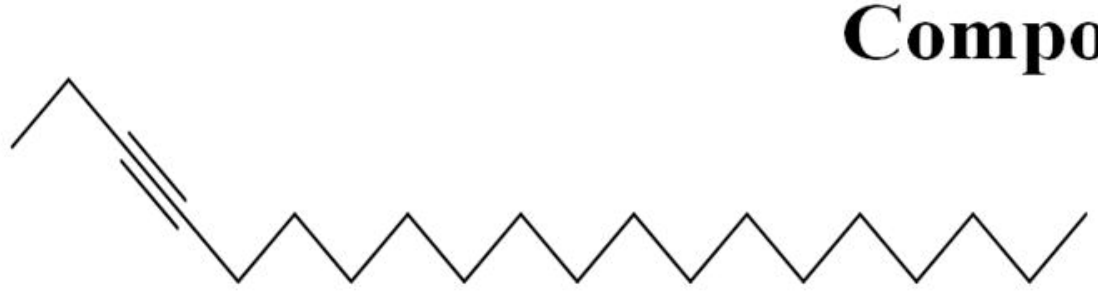

Compound 5

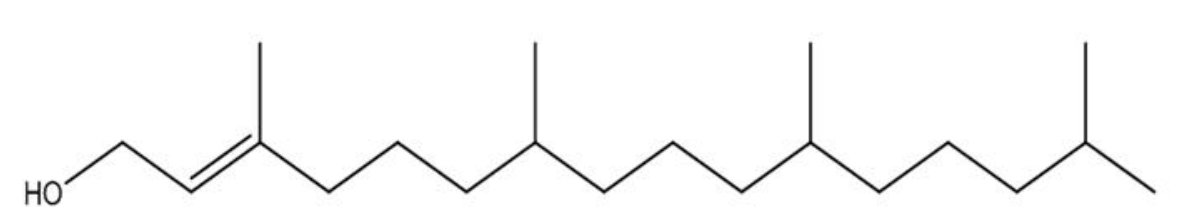

Compound 8

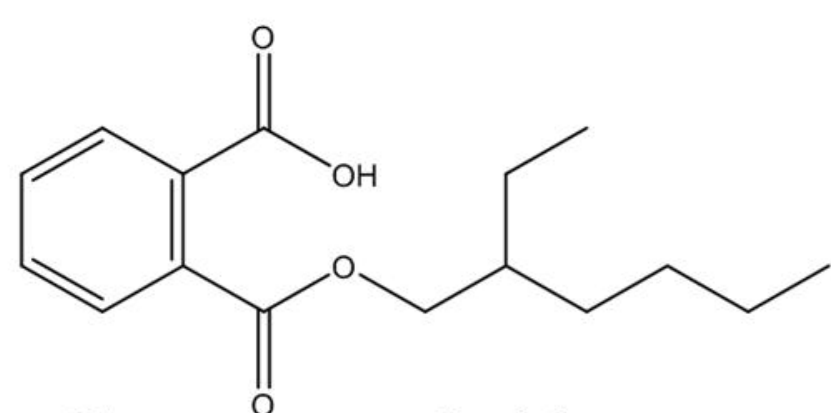

Compound 11

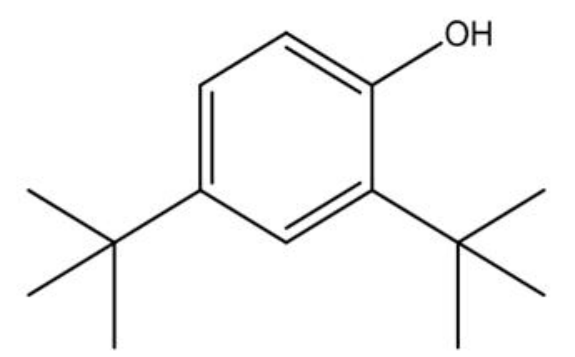

Compound 15

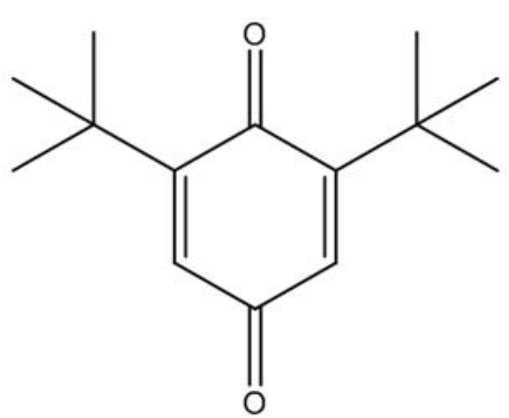

Compound 2

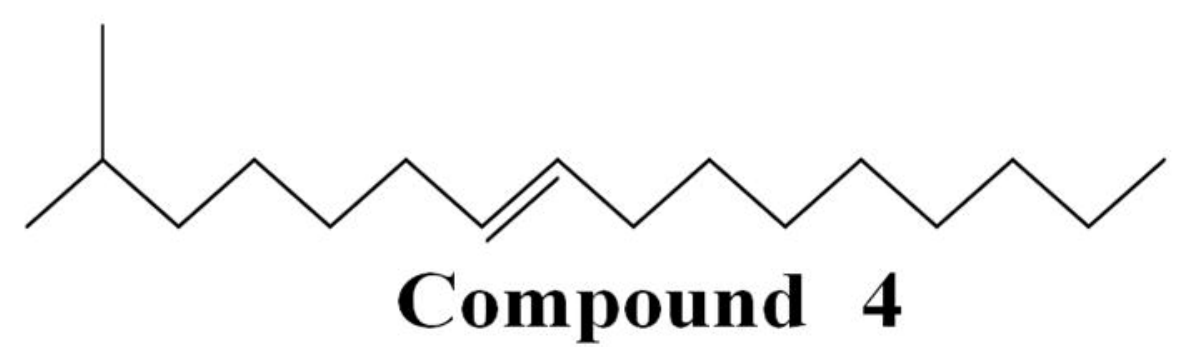

Compound 3

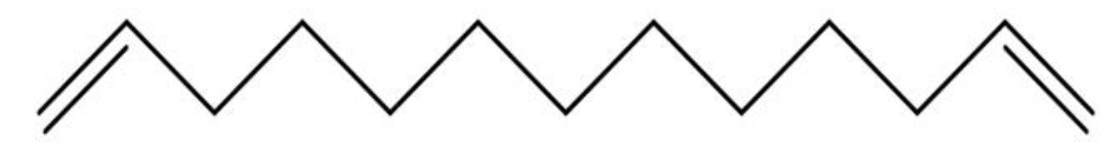

Compound 6

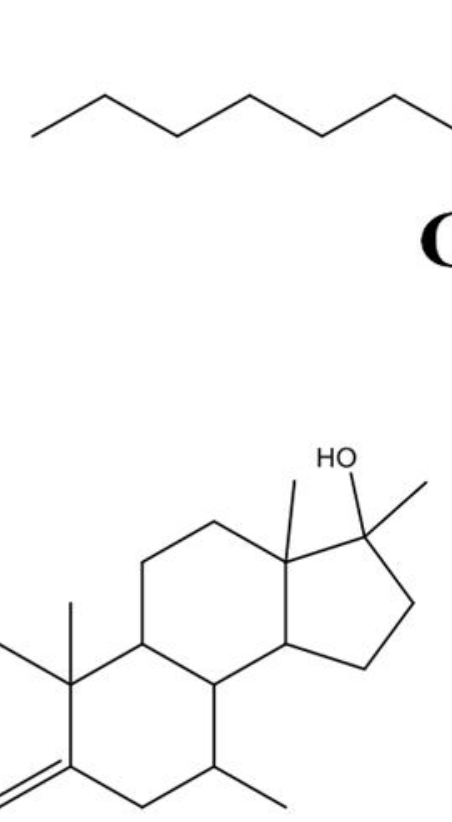

Compound 12

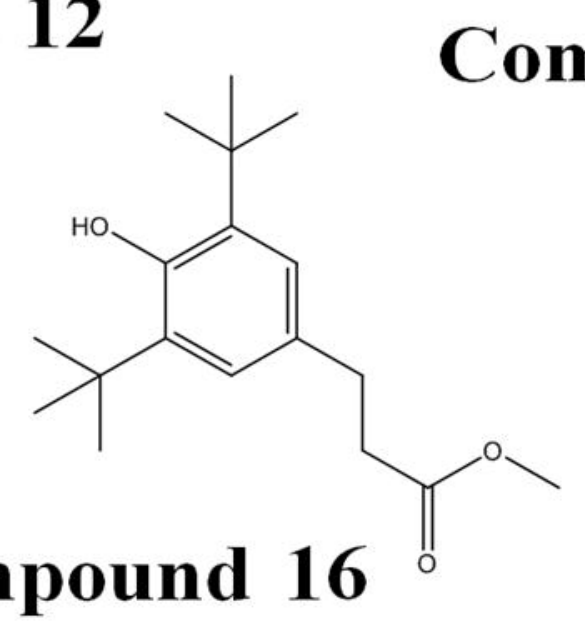

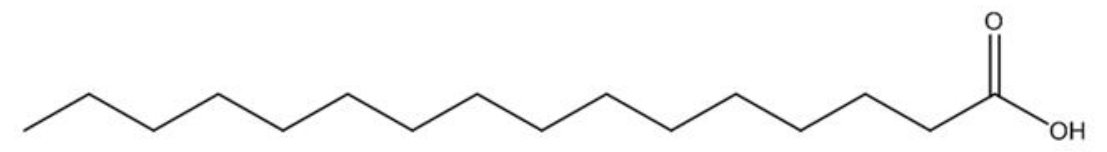

Compound 7

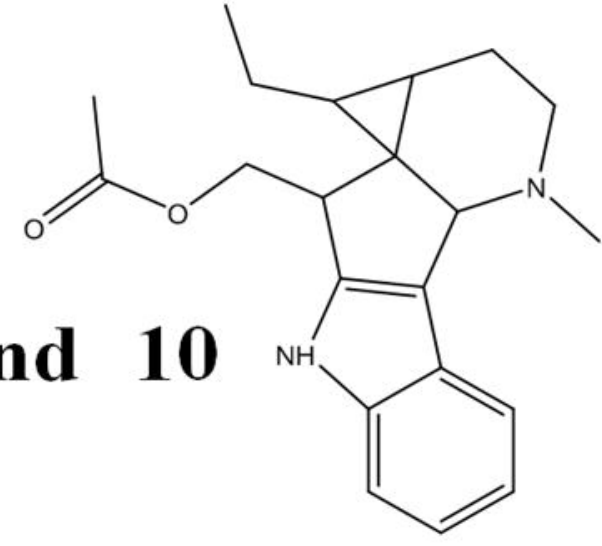

Compound 9

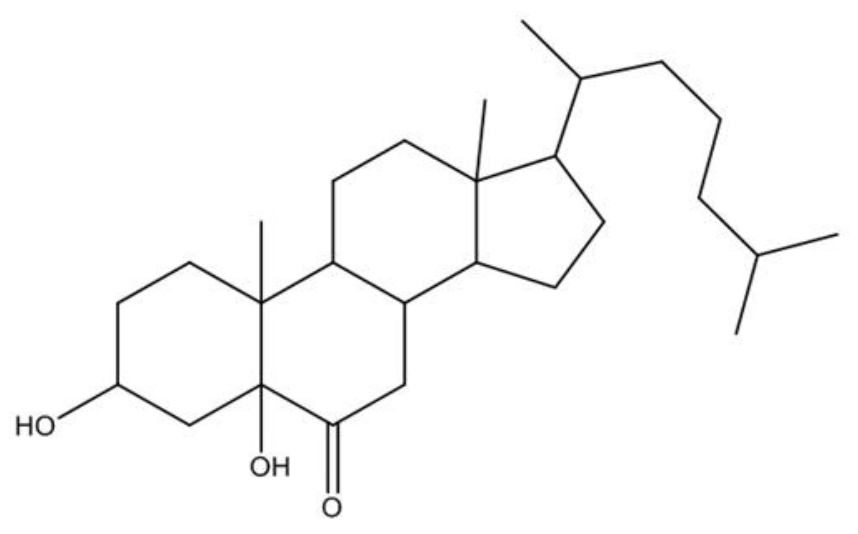

Compound 13
Compound 10

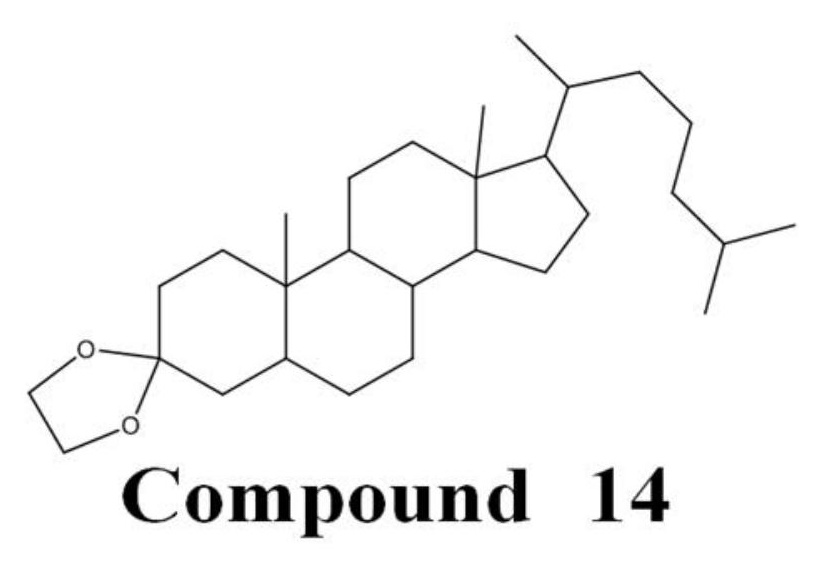

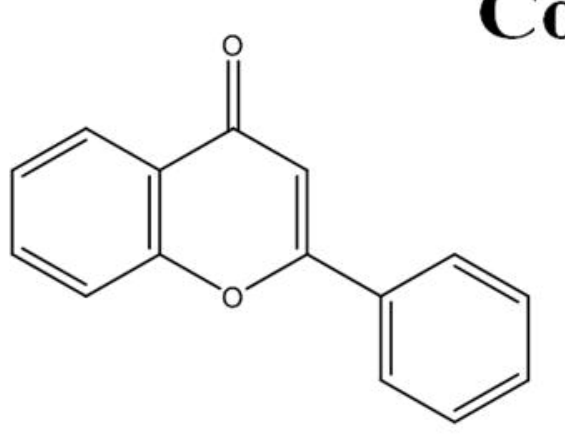

Compound 17 


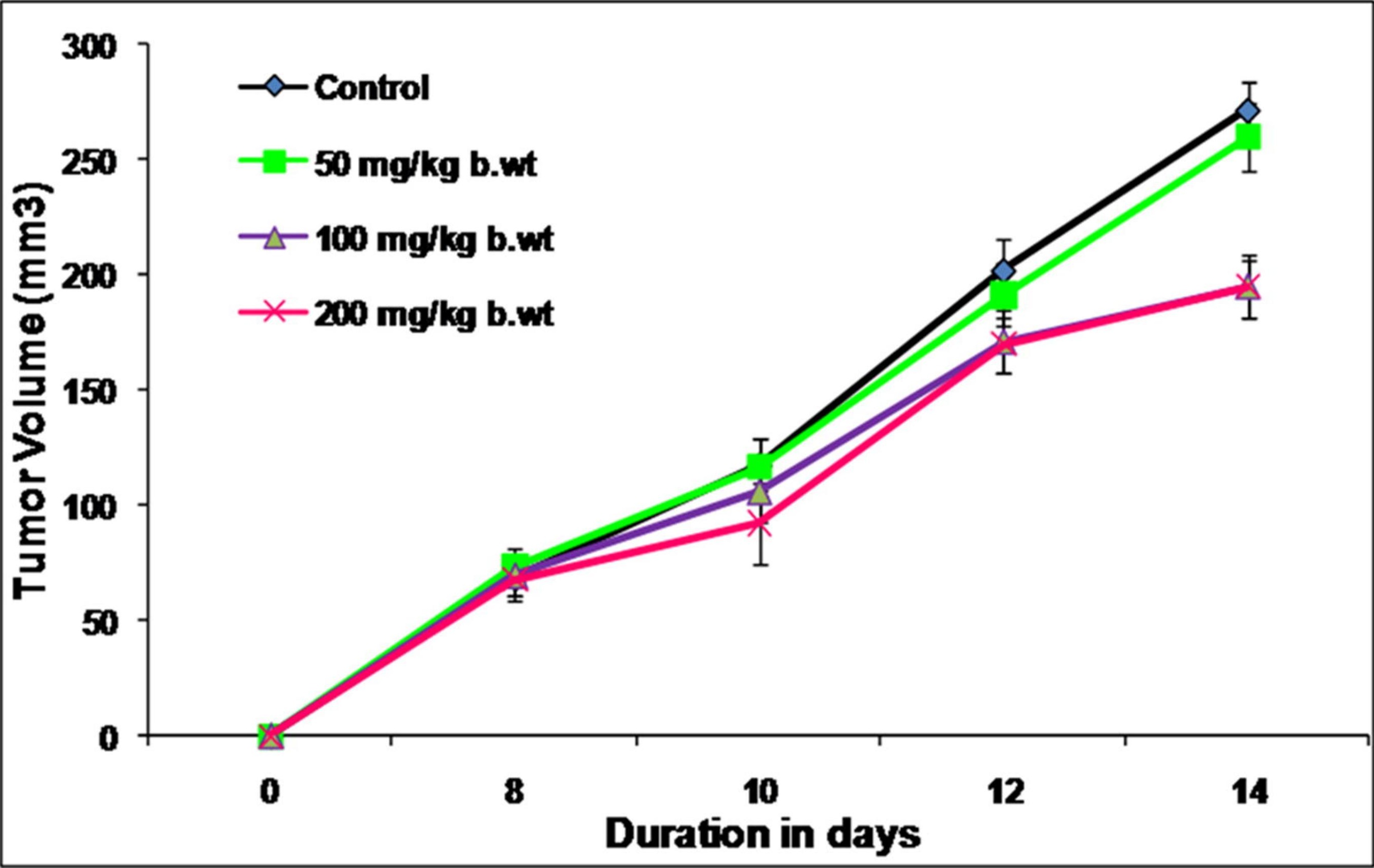


